\title{
Assessing the effects of a trawling ban on diet and trophic level of hake, Merluccius merluccius, in the southern Tyrrhenian Sea
}

\author{
MAURO SINOPOLI ${ }^{1}$, EMANUELA FANELLI ${ }^{2}$, GIOVANNI D’ $^{\prime}$ ANNA $^{3}$, \\ FABIO BADALAMENTI ${ }^{3}$ and CARLO PIPITONE ${ }^{3}$
}

${ }^{1}$ ISPRA sts Palermo, Via S. Puglisi 9, 90143 Palermo, Italy. E-mail: mauro.sinopoli@isprambiente.it

${ }^{2}$ Institut de Ciències del Mar, CSIC, Passeig Maritim de la Barceloneta 37-49, 08003 Barcelona, Spain. ${ }^{3}$ CNR - IAMC, Via G. da Verrazzano 17, 91014 Castellammare del Golfo, Italy.

\begin{abstract}
SUMMARY: This study assesses the effects of a trawling ban on the diet and trophodynamics of the hake Merluccius merluccius by comparing stomach contents and stable isotopes $\left(\delta^{15} \mathrm{~N}\right.$ and $\left.\delta^{13} \mathrm{C}\right)$ in two trawled gulfs and one untrawled gulf in northern Sicily (western Mediterranean). Comparisons were made for three size classes of hake encompassing 60 to 410 $\mathrm{mm}$ total length. Fish were collected from 50 to $200 \mathrm{~m}$ depth on muddy bottoms. The diets of hake of small and medium size were similar overall but more selective in the untrawled gulf. Greater differences were detected between the diets of larger specimens from trawled and untrawled areas. In the untrawled gulf large hake mainly preyed on clupeoid fish, while in the trawled gulfs other fish prey were found in the stomach contents. $\delta^{15} \mathrm{~N}$ values of hake did not vary significantly between trawled and untrawled areas, while there was a clear effect of size, with larger individuals being significantly more enriched than juveniles. Conversely, $\delta^{13} \mathrm{C}$ values were generally more depleted for individuals collected in the untrawled area, suggesting a more pelagic source of carbon. The results from the mixing model agree fairly well with the known feeding habits found for each size class in each area.
\end{abstract}

Keywords: diet, fishing impact, Merluccius merluccius, stable isotopes, trophodynamics, Mediterranean.

RESUMEN: EFECTOS DE UN ÁREA DE VEDA A LA PESCA DE ARRASTRE SOBRE LA DIETA Y EL NIVEL TRÓFICO DE LA MERLUZA, MerluCCIUS merluCCIUS, EN El SUR Del MAR TirReno. - Este estudio evaluó los efectos de la pesca de arrastre comercial en la dieta y la trofodinámica de la merluza mediterránea, Merluccius merluccius, mediante la comparación de sus contenidos estomacales y de la composición isotópica $\left(\delta^{15} \mathrm{~N}\right.$ y $\left.\delta^{13} \mathrm{C}\right)$ en dos golfos donde está permitida la pesca de arrastre y en uno donde está prohibida, en el norte de Sicilia (Mediterráneo Occidental). Las comparaciones se hicieron para tres clases de talla que abarca la merluza entre 60 y $410 \mathrm{~mm}$ de longitud total. Los peces fueron recolectados en los fondos fangosos de la plataforma continental de 50 a $200 \mathrm{~m}$ de profundidad. Los hábitos alimenticios de las merluzas pequeñas y medianas eran similares, pero más selectivo en el golfo donde la pesca está prohibida. Las mayores diferencias se produjeron en la dieta de los especímenes más grandes comparando los golfos arrastrados con el golfo protegido. En el área protegida las merluzas grandes cazaban sobre todo en clupeidos y engráulidos, mientras que otros peces se encuentran en el contenido estomacal de M. merluccius de las áreas de pesca. Los valores de $\delta^{15} \mathrm{~N}$ de la merluza no variaron significativamente entre las áreas protegidas y no protegidas, mientras que hubo un efecto claro de la talla: valores más alto, se han observado en los animales más grandes. Por el contrario los valores de $\delta^{13} \mathrm{C}$ fueron en general más empobrecidos (más negativos) en los ejemplares recolectados en el área protegida, esto indica una fuente más planctónica de carbono. Los resultados de los mixing models concuerdan bastante bien con los hábitos de alimentación observados para cada clase de talla y en cada área.

Palabras clave: dieta, efecto de la pesca, Merluccius merluccius, isótopos estables, trofodinámica, Mediterráneo.

\section{INTRODUCTION}

Trawling has many effects on marine ecosystems, including reduction of fish abundance and mean body size, decrease in diversity (Greenstreet and Hall 1996, Bianchi et al. 2000) and physical habitat damage (Jennings and Kaiser 1998). Trawling modifies the ecosystem structure and species interactions, with nu- 
merous consequences including changes in the trophodynamics. A mix of direct and indirect effects is often observed at the food web level, the main one being a decrease in the mean trophic level as a consequence of the removal of larger individuals, which are generally predators (Bianchi et al. 2000, Pauly et al. 1998). Changes in the diet of fish can occur because of extra supply of organic matter from organisms killed or injured by the trawl gear and from discards that become food for opportunistic species (Kaiser and Spencer 1994). A significant change in feeding habits was observed in juvenile plaice Pleuronectes platessa because of bottom disturbance that increased the abundance of small infaunal invertebrates (Hiddink et al. 2008).

The physical impact of trawl gear on the seafloor also disturbs the sediment and affects its resuspension with the consequent release of buried organic matter (Smith et al. 2000, Olsgard et al. 2008). This may become an alternative source of energy, leading to an increase in the abundance of benthic motile suspensiondeposit feeders (e.g. some amphipods and cumaceans), which in turn are a food source for many benthopelagic fish (Jennings and Kaiser 1998). Persistent trawling may also benefit short-lived benthic organisms that represent important items in the diet of demersal fish (Engel and Kvitek 1998).

Total or partial no-take zones provide useful control areas for investigating the dynamics of recovery from fishing (Murawski et al. 2000, Badalamenti et al. 2002). Increase in fish biomass in recovered areas may lead to higher intra- and interspecific competition as soon as fish density approaches the carrying capacity of the ecosystem (Sánchez Lizaso et al. 2000). One possible effect of increased competition is a diet shift towards resources that are usually less exploited (Ward et al. 2006, Svanbäck et al. 2008). The Gulf of Castellammare is a no-trawl area where a clear recovery of the shelf demersal fish biomass has been recorded (Pipitone et al. 2000) and the effects of protection on the trophodynamics of fish has been investigated (Badalamenti et al. 2008, Fanelli et al. 2009b, 2010). The hake Merluccius merluccius (L., 1758), one of the most important commercial species from Mediterranean muddy bottoms (Oliver and Massuti 1995) where it is heavily exploited (FAO 2005, Lloris et al. 2005), underwent a 4.7-fold average increase on the shelf of the Gulf of Castellammare as a consequence of the trawling exclusion (Pipitone et al. 2000). The hake is a predator (Bozzano et al. 2005, Carpentieri et al. 2005) living between 20 and $1000 \mathrm{~m}$ but more abundant on the lower shelf and upper slope (Relini et al. 1999). It actively preys on fish, crustaceans and cephalopods, showing an opportunistic feeding strategy (Pillar and Barange 1993, Bozzano et al. 2005). The high variability of its feeding habits is probably an evolutionary consequence of its wide bathymetric distribution (Cartes et al. 2004, 2009, Carpentieri et al. 2005). Like most fish species, hake undergo ontogenetic dietary changes: young hake of up to $11 \mathrm{~cm}$ total length feed exclusively on euphausiids and mysids, while those between 12 and $16 \mathrm{~cm}$ feed on nektobenthic decapods and to a lesser extent on small fish and cephalopods. The diet of larger hake is exclusively based on pelagic and nektobenthic fish (mainly clupeoids and gobiids, respectively) (Carpentieri et al. 2005). Furthermore, juvenile hake undergo nycthemeral vertical migrations characterized by a nocturnal upward movement along the water column (Orsi Relini et al. 1997) which affects their feeding strategy (Modica et al. 2011).

This study makes use of stomach content analysis and stable isotope analysis from three areas of the western Mediterranean subject to different trawling pressures to assess the effects of a trawling ban on the diet and trophodynamics of hake. Comparisons were carried out on three size classes of hake, and for each of these a different hypothesis was postulated:

For the first size class, represented by smaller hake feeding mainly on pelagic invertebrates (Carpentieri et al. 2005), we do not expect any difference in the diet between trawled and untrawled areas because their prey is not affected by bottom trawling.

For the second size class we expect a large dietary contribution from nektobenthic decapods in the trawled areas, as recorded in other fishing grounds (Carpentieri et al. 2005), while in the untrawled area we expect a more diversified diet with a significant contribution from pelagic and nektobenthic prey because of higher inter- and intraspecific competition and wider prey availability caused by the absence of trawling impact.

For the almost exclusively piscivorous larger hake belonging to the third size class we expect a high feeding intensity on nektobenthic fish in the trawled areas. In the untrawled area hake may well be submitted to higher intra- and interspecific competition due to higher fish biomass, so they are expected to differentiate their diet by exploiting both nektobenthic and pelagic resources.

\section{MATERIALS AND METHODS}

\section{Study site}

The study was carried out in three areas located along the northern coast of Sicily (western Mediterranean), the Gulfs of Castellammare (GCAST), Termini Imerese (GTERM) and Sant'Agata (GSANT) (Fig. 1). GCAST is a fishery exclusion zone which has been subject to a trawling ban since 1990 (Pipitone et al. 2000). At GTERM and GSANT trawling is normally practiced at a depth greater than $50 \mathrm{~m}$, according to the national legislation. These two gulfs are heavily exploited by a large trawling fleet and can be considered subject to comparable trawling effort and both overfished (Greco 1994). The three areas are characterized by central sandy shores with rocky cliffs at the outer edges and by soft bottoms, except immediately below the cliffs where rocky substrates dominate. According to Fanelli et al. (2011) trophic (chlorophyll $a$ concen- 


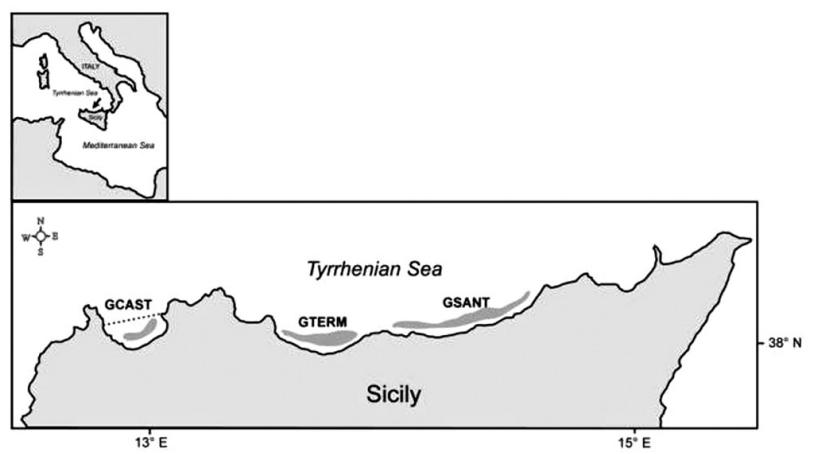

Fig. 1. - Study area; GCAST, Gulf of Castellammare; GTERM, Gulf of Termini Imerese; GSANT, Gulf of S. Agata

tration) and chemical-physical conditions (temperature, salinity) are similar in the three areas.

\section{Sample collection}

Hakes were collected by bottom otter trawl using a hired professional fishing vessel between 17 May and 14 June 2005 on muddy bottoms at 50 to $200 \mathrm{~m}$ depth during daytime.

Benthopelagic macrofauna, which is a known food resource for hake, was sampled at the same time and site by means of a modified Macer-GIROQ suprabenthic sledge and data were used in the mixing model (see below). Fish and suprabenthic samples were frozen on board immediately after collection, and then transferred to the laboratory.

\section{Sample treatment and stomach content analysis}

In the laboratory hakes were individually measured and weighed. In order to reach a representative sample size for stomach content analysis we decided to collect 30 full stomachs for each area and for each of the following three size classes: class I from 60 to $120 \mathrm{~mm}$ total length (TL), class II from 121 to $220 \mathrm{~mm}$ TL, and class III from 221 to $410 \mathrm{~mm}$ TL. Stomachs that externally appeared full after dissection were removed and preserved in $80 \%$ ethanol. For class III from GTERM only 12 full stomachs were analysed due to low abundance of hake in the catch. Preys in each stomach were identified to the lowest possible taxonomic level, counted and weighed (precision: 0.0001 g). Fragmented prey count was based on the number of eyes, mouth parts, telsons, otoliths or other anatomical parts traceable to single specimens.

Individuals in benthic samples were identified to the lowest possible taxonomic level, counted, weighed and prepared for stable isotope analysis (Fanelli et al. 2009a).

\section{Data analysis}

In order to investigate the hake population structure in the three gulfs, a length-frequency plot was made using density data (ind. $\mathrm{km}^{-2}$ ). A comparison of density data on the two orthogonal factors Gulf and Size was then performed using a univariate PERMANOVA (Anderson 2001) carried out on Euclidean distances.

For stomach content analysis the following indices of prey importance were calculated (see Hyslop, 1980 for a review): per cent frequency of occurrence $(\% \mathrm{~F})$, per cent numerical composition $(\% \mathrm{~N})$, per cent gravimetric composition $(\% \mathrm{~W})$ and index of relative importance $(\mathrm{IRI})=(\% \mathrm{~N}+\% \mathrm{~W}) \times \% \mathrm{~F}($ Pinkas et al. 1971), expressed as $\%$ IRI $=($ IRI/ $\Sigma$ IRI $) \times 100$. In the results we reported $(\% \mathrm{~N})$ and $(\% \mathrm{IRI})$ of each prey item in each size class of hake in each gulf and for all the statistical comparisons we used $(\% \mathrm{~N})$.

In order to ordinate stomachs on the basis of their correlation with the factors Gulf and Size, a CCA plot (Correlative Correspondence Analysis: Anderson and Willis, 2003) was performed on a modified Gower resemblance matrix based on fourth-root transformed numerical abundance data of prey items. Prey with a higher value of correlation, responsible for allocation of stomach in the plot, were superimposed in the graph.

Based on the null hypothesis that there are no differences in the diet of hake between untrawled and trawled areas and within size classes, an asymmetrical PERMANOVA design (Anderson 2001) was performed on three factors: factor 1 Trawl, fixed with 2 levels (Tr and UTr, i.e. trawled and untrawled); factor 2 Gulf, random with 3 levels (GCAST, GTERM and GSANT) nested in Trawl; factor 3 Size, fixed with 3 levels (I, II and III) crossed with Trawl and Gulf.

All identified prey items were grouped in ecological categories based on their habitat, feeding habits and life cycle as follows: long life span benthic carnivores (LLSBC), short life span benthic carnivores (SLSBC), pelagic planktivorous fish (PPF), planktonic planktivorous invertebrates (PPI) and suprabenthic suspensiondeposit feeders (SBSF) (Table 1). For each category the per cent numerical contribution per area and size class of hake was calculated. The allocation of prey to the above categories was based on Fishbase (http:// www.fishbase.org) for fish, on Sealifebase (http:// www.sealifebase.org) for cephalopods and on bibliographic data (Sainte-Marie and Brunel 1985, Cartes et al. 2002, Fanelli et al. 2009a) for crustaceans.

Trophic niche breadth was calculated by means of the Levin standardized index (Krebs 1989) as follows:

$$
B_{i}=\frac{1}{n-1}\left(\frac{1}{\sum_{j} p_{i j}^{2}}-1\right)
$$

where $B_{i}$ is the Levin standardized index for predator $i, \mathrm{p}_{i j}$ is the proportion of prey $j$ in the diet of predator $i$, and $n$ is the number of prey categories. This index varies from 0 to 1 , with low values indicating a diet dominated by few preys (a specialized feeder) and high values indicating a diet dominated by numerous preys (a generalist feeder) (Gibson and Ezzi 1987). 
TABLE 1. - List of prey items with ecological category. LLSBC, long life span benthic carnivores; SLSBC, short life span benthic carnivores; $\mathrm{PPF}$, pelagic planktivorous fish; PPI, planktonic planktivorous invertebrates; SBSF, supra benthic suspension-deposit feeders. Information on habitats, feeding habits and life cycles were obtained from (1) Fishbase (http://www.fishbase.org); (2) Sealifebase (http://www.sealifebase. org); (3) Cartes et al. (2002); (4) Fanelli et al. (2009a); and (5) Sainte-Marie and Brunel (1985).

\begin{tabular}{|c|c|c|c|c|c|}
\hline & Category & Source & & Category & Source \\
\hline Fish & & & Crustaceans & & \\
\hline Antonogadus megalokydon & LLSBC & (1) & Alpheus glaber & SLSBC & (3) \\
\hline Cepola macrophthalma & LLSBC & (1) & Parapenaeus longirostris & SLSBC & (3) \\
\hline Deltentosteus quadrimaculatus & LLSBC & (1) & Scyllarus cfr arctus & SLSBC & (3) \\
\hline Gadiculus argenteus & LLSBC & (1) & Solenocera membranacea & SLSBC & (3) \\
\hline Gadide & LLSBC & (1) & Pontocaris lacazei & SLSBC & (3) \\
\hline Gobius niger & LLSBC & (1) & Processa sp. & SLSBC & (3) \\
\hline Merluccius merluccius & LLSBC & (1) & Rocinela dumerili & SLSBC & (4) \\
\hline Mullus barbatus & LLSBC & (1) & Euphausiacea & PPI & (3) \\
\hline Scorpaenidae & LLSBC & (1) & Decapoda Larvae & PPI & (3) \\
\hline Triglidae & LLSBC & (1) & Osteichthyes larvae & PPI & (1) \\
\hline Lesueurigobius suerii & LLSBC & (1) & Lophogaster typicus & SBSF & (3) \\
\hline Argentina sphyraena & PPF & (1) & Mysidacea & SBSF & (5) \\
\hline Sardina pilchardus & PPF & (1) & Ampelisca typica & SBSF & (4) \\
\hline Engraulis encrasicolus & PPF & (1) & Dyastilis sp. & SBSF & (5) \\
\hline Paralepis speciosa & PPF & (1) & Monoculodes sp. & SBSF & (5) \\
\hline Sardinella aurita & PPF & (1) & & & \\
\hline Spicara sp. & PPF & (1) & Cephalopods & & \\
\hline Trachurus trachurus & PPF & (1) & Sepietta $\mathrm{sp}$ & SLSBC & $(2)$ \\
\hline Lepidopus caudatus & PPF & (1) & & & \\
\hline
\end{tabular}

\section{Stable isotope analysis}

A portion of white muscle below the dorsal fin was taken from three replicate hake of a similar size from each size class $(93.0 \pm 1.9 \mathrm{~mm}$ for class I; $166.6 \pm 33.2$ $\mathrm{mm}$ for class II; $273.6 \pm 60.9 \mathrm{~mm}$ for class III) and prepared for nitrogen and carbon stable isotope analysis. Samples were oven-dried to constant weight at $60^{\circ} \mathrm{C}$, then ground to a fine powder and weighed into tin cups. Using continuous flow, the samples were placed in a Finnigan Delta XP-plus isotope ratio mass spectrometer for isotopic analysis. Three capsules of a certified internal standard were analysed at the beginning of each sequence as well as one in every six samples, to compensate for machine drift and as a quality control measure. $\delta^{13} \mathrm{C}$ and $\delta^{15} \mathrm{~N}$ values were expressed in parts per thousand $(\% o$ ) relative to Vienna Pee Dee Belemnite (vPDB) and atmospheric $\mathrm{N}_{2}$ standards, respectively, according to the following formula: $\delta^{13} \mathrm{C}$ or $\delta^{15} \mathrm{~N}=$ $\left[\left(R_{\text {sample }} / R_{\text {standard }}\right)-1\right] \times 10^{3}$ where $R={ }^{13} \mathrm{C} /{ }^{12} \mathrm{C}$ or ${ }^{15} \mathrm{~N} /{ }^{14} \mathrm{~N}$.

Since lipids were not extracted from fish tissues in our study, $\delta^{13} \mathrm{C}$ values were normalized for lipid concentration according to Kiljunen et al. (2006). Thus, $\delta^{13} \mathrm{C}$ values of untreated (i.e. not defatted) samples were converted to normalized $\delta^{13} \mathrm{C}\left(\delta^{13} \mathrm{C}_{\text {lipidfree }}\right)$ following the lipid normalization model of McConnaughey and McRoy (1979) based on two equations, where Equation 2 was modified as follows:

$$
\begin{gathered}
L=\frac{93}{1+(0.246 \times(C / N)-0.775)^{-1}} \\
\delta^{13} C_{\text {lipidfree }}=\delta^{13} C_{\mathrm{U}}+D \times\left(I+\frac{3.90}{1+287 / L}\right)
\end{gathered}
$$

where $L$ is the proportional lipid content in the sample, $\mathrm{C}$ and $\mathrm{N}$ are the proportions of carbon and nitrogen in the sample, $\delta^{13} \mathrm{C}_{\mathrm{U}}$ is the untreated value in the sample, $D$ is the isotopic difference between proteins and lipids (re-estimated by Kiljunen et al. 2006 as equal to $7.018 \pm 0.263$ ) and $I$ is a constant (assigned a value of $0.048 \pm 0.013$ by Kiljunen et al. 2006). The $\delta^{13} C_{\text {lipidfree }}$ values obtained with this method were compared with those generated by the equation proposed by Logan et al. (2008):

$$
\delta^{13} \mathrm{C}_{\text {lipidfree }}=0.967 \times \delta^{13} \mathrm{C}_{\mathrm{U}}+0.861
$$

Hereafter we have used the term model 1 for Equation 2 and model 2 for Equation 3.

\section{Trophic level estimates}

According to the literature (Bozzano et al. 2005, Carpentieri et al. 2005, Cartes et al. 2009), hake is connected to a pelagic food web, so copepods were chosen as reference material for the trophic level (TrL) estimate. $\delta^{15} \mathrm{~N}$ values of hake were converted to $\mathrm{TrL}$ based on the assumption that there is a fractionation of ca. 3.4\%o per trophic level (Minagawa and Wada 1984, Post 2002) and that the reference material (calanoid copepods, mean $\delta^{15} \mathrm{~N}=3.5 \pm 0.5$ ) have a trophic level of 2 :

$$
\operatorname{Tr} L=\left(\frac{\delta^{15} \mathrm{~N}-\delta^{15} \mathrm{~N}_{\text {ref }}}{3.4}\right)+2
$$

where $\delta^{15} \mathrm{~N}$ is the mean $\delta^{15} \mathrm{~N}$ value of hake, and $\delta^{15} \mathrm{~N}_{\text {ref }}$ is the mean $\delta^{15} \mathrm{~N}$ value of copepods. Trophic level was also estimated by TrophLab (Pauly et al. 2000) and the two estimates were compared.

\section{Mixing models}

The limitations of using geometric procedures to determine dietary contributions of three or more food sources using $\delta^{13} \mathrm{C}$ and $\delta^{15} \mathrm{~N}$ (Philipps 2001, Schindler 


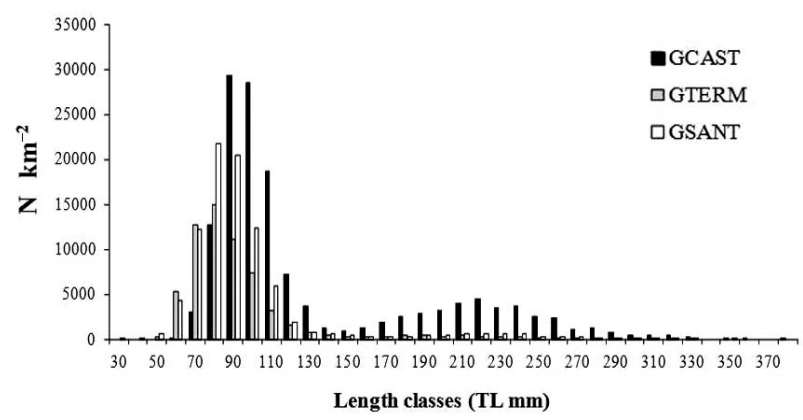

Fig. 2. - Length-frequency distribution $\left(\mathrm{N} \mathrm{km}^{-2}\right)$ of hake in the three gulfs. GCAST, Gulf of Castellammare; GTERM, Gulf of Termini Imerese; GSANT, Gulf of Sant'Agata

and Lubetkin 2004), the broad range of potential food sources, and the limitations inherent in a one-month sampling without temporal replication called for the use of a stable isotope mixing model as implemented in the software package IsoSource (Philipps and Gregg 2003). IsoSource employs a mass balance approach to estimate the range of all possible diet proportions from $0 \%$ to $100 \%$ for as many as ten contributing food sources. The IsoSource user supplies the isotopic signatures of the sources (the prey) and the mixture (in our case the hake), along with the desired source increment (1\%) and the mass balance tolerance $(0.1 \%$ ) . The output files include all the feasible source combinations, with histograms and descriptive statistics on the distributions for each source. Isotopic signatures of the sources include the isotopic values of the dominant items in the diet throughout the whole sampling period (data of prey species used in the mixing model are available in Fanelli et al. 2009a, 2011; authors' unpubl. data). We also considered a per-step 3\%o trophic fractionation between hake and their prey according to Post et al. (2002). For mixing model computations, $\delta^{13} C_{\text {lipidfree }}$ values were used.

\section{RESULTS}

\section{Population structure and density}

Length-frequency data of hake (Fig. 2) showed a two-mode distribution at GCAST, one including fish of 50-130 mm and the other including fish of 160-330 $\mathrm{mm}$. Length frequencies in the trawled gulfs showed only one mode $(50-130 \mathrm{~mm})$ and very low density values in larger size groups.

Univariate PERMANOVA (Table 2A) showed a significant interaction between the factors Gulf and Size. The pairwise comparison showed significantly higher density of class II and III hake in GCAST than in GSANT and GTERM, while no difference was detected for class I hake.

\section{Spatial variations in stomach contents}

A total of 768 prey items belonging to 44 taxa were identified in the stomach contents of hake from the three areas (Appendix 1). The diet of class I hake was dominated by euphausiids in the three areas, with a higher amount in GTERM $(70.63 \% \mathrm{~N}, 53.72 \%$ IRI) than in GSANT $(62.94 \% \mathrm{~N}, 46.91 \%$ IRI) and GCAST (58.14\%N, 57.88\%IRI) (Fig. 3A). Mysids contributed to the diet of hake in all areas, especially in GCAST (15.12\% N for total mysids). Shrimps (especially Chlorotocus crassicornis and Processa sp.) and fish (especially Lesueurigobius suerii and Gadiculus argenteus) were secondary items in the diet of smaller hake.

The diets of class II hake (Fig. 3B) were similar in the three gulfs, with some differences in the contribution of the main prey. In GCAST hake preyed mainly on Sardina pilchardus $(32.69 \% \mathrm{~N}, 64.83 \% \mathrm{IRI})$ and on unidentified fish $(26.92 \% \mathrm{~N}, 25.10 \%$ IRI), while other fish, euphausiids and unidentified crustaceans were secondary prey items. In the two trawled gulfs
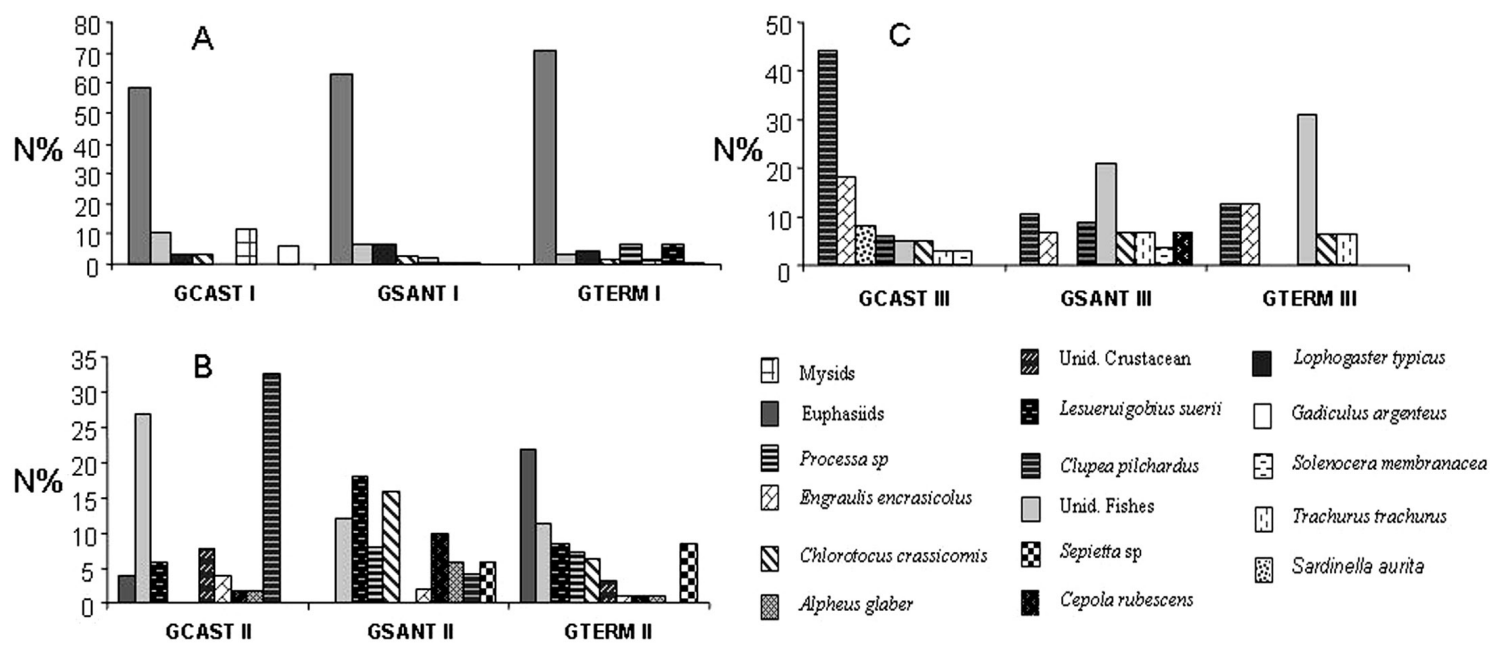

Fig. 3. - Per cent abundance (N\%) of main prey items in the stomach contents of hake for the three classes in the three gulfs. GCAST, Gulf of Castellammare; GTERM, Gulf of Termini Imerese; GSANT, Gulf of Sant'Agata; I, size class I (60-120 mm TL); II, size class II (121-220 $\mathrm{mm}$ TL); III, size class III (221-410 mm TL). 
TABLE 2. - A, results of PERMANOVA performed on density of hake for the two factors Gulf and Size. B, results of PERMANOVA performed on $\mathrm{N} \%$ for each prey item in the three gulfs and in the three size classes. *, $P<0.05$; **, $P<0.01$; n.s., not significant; GCAST, Gulf of Castellammare; GTERM, Gulf of Termini Imerese; GSANT, Gulf of Sant'Agata; I, size class I (60-120 mm TL); II, size class II (121-220 $\mathrm{mm}$ TL); III, size class III (221-410 mm TL).

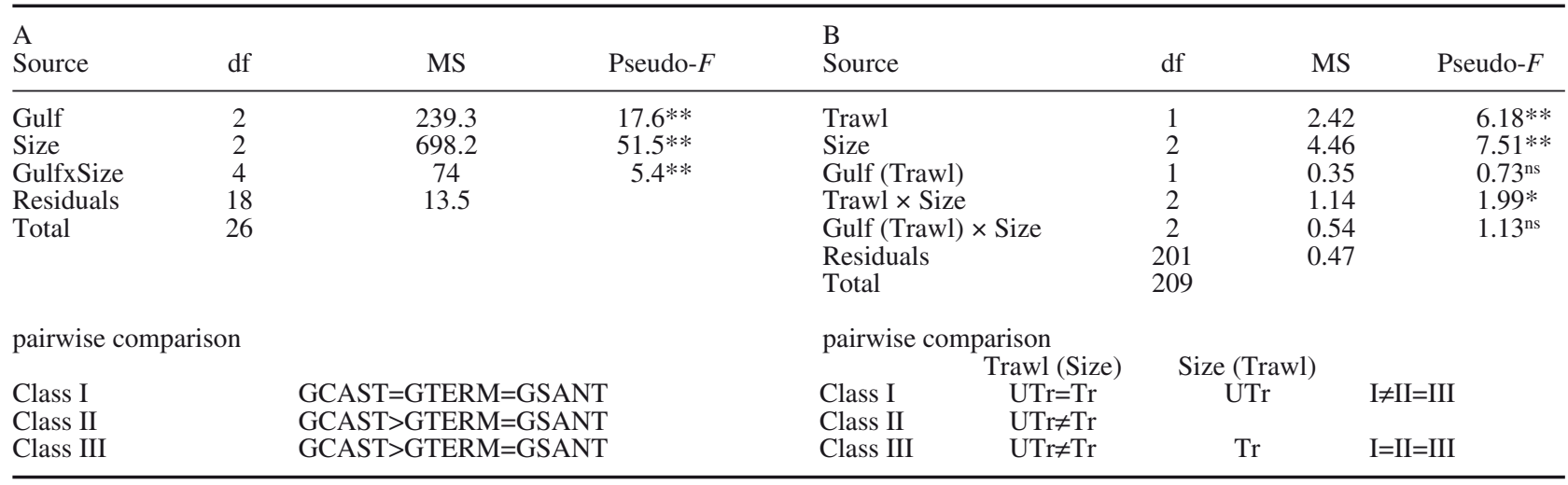

a wider array of prey categories contributed to the diet (Fig. 3B). In GTERM the main contribution was provided by euphausiids $(21.88 \% \mathrm{~N}, 5.71 \% \mathrm{IRI})$, Sepietta sp. $(8.33 \% \mathrm{~N}, 15.85 \%$ IRI) and L. suerii $(8.33 \% \mathrm{~N}$, $8.90 \%$ IRI), followed by amphipods, shrimps (mainly C. crassicornis and Processa sp.) and unidentifed fish. In GSANT the diet was dominated by $L$. suerii $(18.00 \% \mathrm{~N}, 18.49 \% \mathrm{IRI})$ and C. crassicornis $(16.00 \% \mathrm{~N}$, $16.15 \%$ IRI), followed by other shrimps (mainly $\mathrm{Al}$ pheus glaber and Processa sp.), Cepola macrophthal$m a$ and unidentified fish.

Hake of size class III in GCAST (Fig. 3C) mainly consumed such pelagic fish as S. pilchardus $(43.88 \% \mathrm{~N}$, $62.85 \%$ IRI), Engraulis encrasicolus $(18.37 \% \mathrm{~N}$, $19.31 \% \mathrm{IRI})$ and Sardinella aurita $(8.16 \% \mathrm{~N}$, $11.81 \%$ IRI), while other fish and shrimps (mainly $C$. crassicornis and Processa sp.) were secondary items. In the trawled gulfs pelagic fish contributed less to the diet of larger hake $(25.00 \% \mathrm{~N}$ and $17.55 \% \mathrm{~N}$ in GTERM and GSANT, respectively, for $S$. pilchardus pooled with E. encrasicolus) and were followed by decapod crustaceans and by the benthopelagic fishes $L$. suerii and Trachurus trachurus. Unidentified fish were abundant in the stomach contents from both trawled gulfs.

\section{CCA ordination and multivariate comparison}

The first axis of CCA ordination, performed on all stomach samples from the three gulfs and for the three size classes, explains $20 \%$ of variance (Fig. 4 ) and is positively correlated with the factors Trawl $(R=0.39)$ and Size $(R=0.51)$. The second axis explains $16 \%$ of variance and is negatively correlated with Trawl $(R=-$ $0.21)$ and positively correlated with Size $(R=0.14)$. The plot shows a segregation of samples into two groups: one group on the left includes samples of size class I from the three areas. Prey correlated with this group were euphausiids and the mysid L. typicus. The same group, at the top, contains samples belonging to size classes II and III from the trawled gulfs and a part of samples belonging to size class III from GCAST. Prey

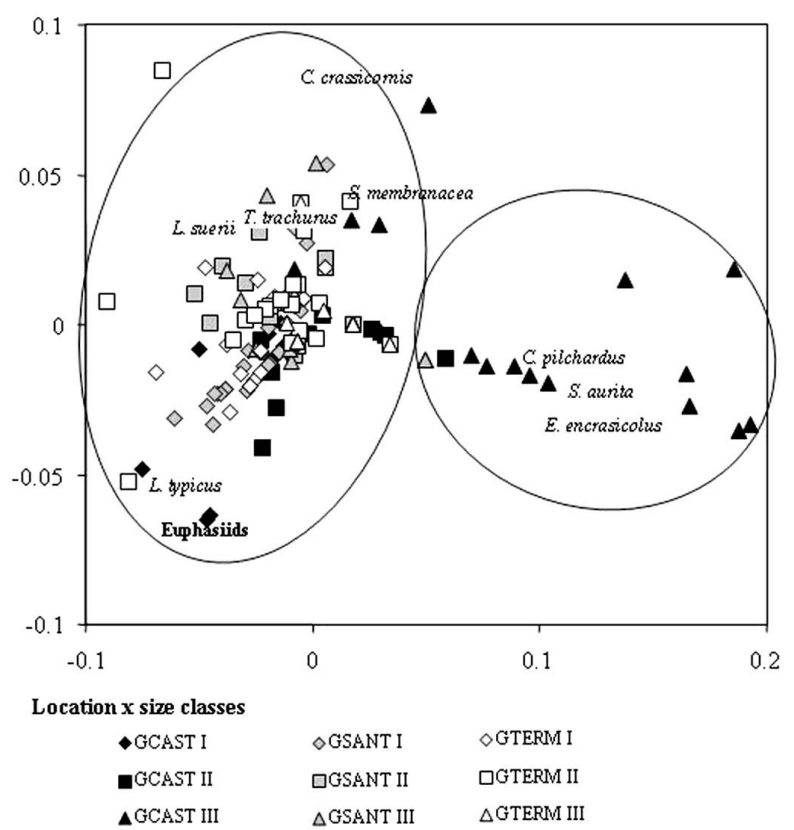

Fig. 4. - CCA (Correlative Correspondence Analysis) ordination performed on all stomach samples for the three gulfs and the three size classes. GCAST, Gulf of Castellammare; GTERM, Gulf of Termini Imerese; GSANT, Gulf of Sant'Agata; I, size class I (6-120 mm TL); II, size class II (121-220 mm TL); III, size class III (221$410 \mathrm{~mm}$ TL).

correlated with these samples were decapods (C. crassicornis and Solenocera membranacea) and fish ( $T$. trachurus and $L$. suerii). In the second group, on the right side of the plot, samples of class III from GCAST were present. These samples were clearly correlated with S. pilchardus, E. encrasicolus and S. aurita.

PERMANOVA showed a significant difference between untrawled and trawled areas (Table 2B) and among size classes, while no differences were found among gulfs. Furthermore a significant interaction between the factors Trawl and Size was found. The pairwise comparison performed on size classes II and III (Table 2B) showed a multivariate difference 

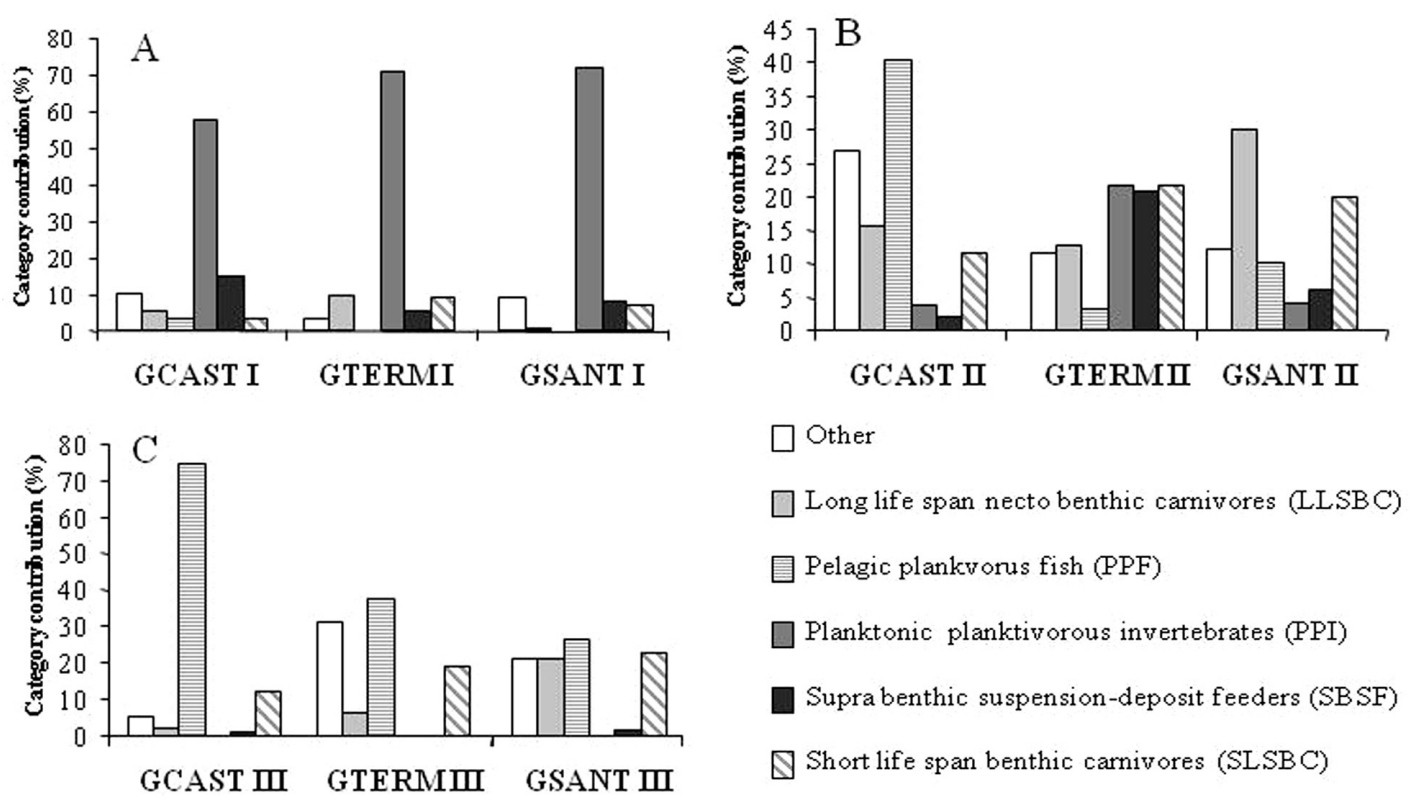

Fig. 5. - Per cent distribution of the ecological categories of prey in the three gulfs for the three size classes. GCAST, Gulf of Castellammare; GTERM, Gulf of Termini Imerese; GSANT, Gulf of Sant'Agata; I, size class I (60-120 mm TL); II, size class II (12-220 mm TL); III, size class III (221-410 mm TL).

between the diets of hake from untrawled vs. trawled areas, but not in the diets of class I hake. Furthermore, the pairwise comparison performed on size classes in GCAST showed a significant difference between class I and classes II-III, while no difference resulted from size classes in the trawled gulfs.

\section{Comparison among ecological categories and niche breadth estimates}

As for the per cent contribution of ecological prey categories to the diet, the trend resembled that observed in the stomach content analysis at species level: for class I hake PPI represented the main food item (58\% to $71 \%$ ) in each gulf, while the other categories contributed less than $15 \%$ (Fig. 5a). PPF were the most important category for class II hake at GCAST $(40.3 \%)$ followed by LLSBC (15.3\%); LLSBC and SLSBC were mainly consumed at GSANT $(30 \%$ and $20 \%$, respectively), while PPI, SBSF and SLSBC mostly contributed to the diet at GTERM (from 20.8 to $21.8 \%$ ) (Fig. 5b). Similarly, PPF dominated the diet of class III hake at GCAST (74.4\%). In the trawled gulfs the contribution of PPF decreased $(26.3 \%$ in GSANT, $37.5 \%$ in GTERM), while that of SLSBC increased (22.8\% in GSANT and $22.7 \%$ in GTERM). In GSANT an increase in the contribution of LLSBB (21.0\%) was also recorded.

A more diverse diet was observed in class I hake in GSANT and GTERM, where on average 17 and 13 different taxa were found, respectively, in stomach contents, while 10 taxa were found on average in GCAST (Table 3). A very narrow niche breadth with a $\mathrm{B}$ index ranging from 0.08 to 0.19 was found for class
I hake in the three gulfs, indicating a specialized foraging strategy in juveniles (Table 3 ). Higher B values were found in class II hake: individuals from GSANT had a wider niche breadth $(B=0.55)$ than those from GTERM $(B=0.40)$ and GCAST $(B=0.37)$. Class III hake in GCAST had a narrower niche breadth $(\mathrm{B}=0.24)$ than those in the trawled gulfs (GSANT $B=0.57$ and GTERM B=0.60).

\section{Stable isotope analysis and trophic level estimates}

Overall, there were an increase in $\delta^{15} \mathrm{~N}$ and an enrichment in $\delta^{13} \mathrm{C}$ with size in all gulfs (Table 3 ). $\delta^{13} \mathrm{C}$ values in hake of all size classes from GTERM and GSANT were generally more enriched (i.e. less negative) than those in GCAST. The same trends were observed when $\delta^{13} C_{\text {lipidfree }}$ values were compared. Since the values obtained by model 1 and those generated by model 2 were similar (Table 3 ) and did not differ statistically, we decided to use model 2 for further lipid corrections of $\delta^{13} \mathrm{C}$ values of prey in the mixing models (see below).

Trophic levels of hake estimated on the basis of $\delta^{15} \mathrm{~N}$ values were generally lower than those calculated with TrophLab (Table 3). Lower trophic levels were obtained with the first method in GCAST because of the higher value of the baseline.

$\delta^{15} \mathrm{~N}$ values of hake did not vary significantly between untrawled and trawled areas, while there was a clear effect of size, with larger individuals being significantly more enriched than smaller ones (Table $4)$. No significant differences occurred among areas and for the interaction terms (Table 4$). \delta^{13} \mathrm{C}$ values varied significantly among size classes and areas and 
TABLE 3. - Number of prey taxa (N) found in the stomach contents of hake from the three gulfs and for each size class. Values of niche breadth (B) according to the Levins index from the three gulfs and for each size class. $\delta^{15} \mathrm{~N}$ and $\delta^{13} \mathrm{C}_{\mathrm{U}}$ values $( \pm \mathrm{SD})$ of hake analysed in each gulf and for each size class. Values of $\delta^{13} \mathrm{C}$ corrected for lipid content according to model $1\left(\delta^{13} \mathrm{C}_{\text {lipidfree }} 1\right)$ and model $2\left(\delta^{13} \mathrm{C}_{\text {lipidfree }} 2\right)(\mathrm{see}$ text for further details). Trophic level estimated on the basis of $\delta^{15} \mathrm{~N}$ values of hake: TrL 1 was calculated considering calanoid copepods as reference material; TrL 2 was calculated using TrophLab (see text for details). GCAST, Gulf of Castellammare; GTERM, Gulf of Termini Imerese; GSANT, Gulf of Sant'Agata. Class I, hake 60-120 mm TL; Class II, hake 121-220 mm TL; Class III, hake 221-410 mm TL.

\begin{tabular}{|c|c|c|c|c|c|c|c|c|}
\hline & $\mathrm{N}$ & B & $\delta^{15} \mathrm{~N}$ & $\delta^{13} \mathrm{C}_{\mathrm{U}}$ & $\delta^{13} C_{\text {lipidfree }} 1$ & $\delta^{13} C_{\text {lipidfree }} 2$ & TrL 1 & $\operatorname{TrL} 2$ \\
\hline \multicolumn{9}{|l|}{ GCAST } \\
\hline Class I & 10 & 0.19 & $8.97 \pm 0.07$ & $-19.97 \pm 0.03$ & $-18.60 \pm 0.03$ & $-18.45 \pm 0.03$ & 3.05 & $4.1(0.4)$ \\
\hline Class II & 17 & 0.09 & $9.52 \pm 0.07$ & $-18.81 \pm 0.03$ & $-17.44 \pm 0.03$ & $-17.32 \pm 0.03$ & 3.06 & $4.5(0.8)$ \\
\hline Class III & 14 & 0.08 & $10.49 \pm 0.07$ & $-18.37 \pm 0.03$ & $-16.61 \pm 0.30$ & $-16.53 \pm 0.29$ & 3.09 & $4.5(0.8)$ \\
\hline \multicolumn{9}{|l|}{ GTERM } \\
\hline Class I & 12 & 0.37 & $8.85 \pm 0.01$ & $-18.47 \pm 0.03$ & $-17.10 \pm 0.03$ & $-17.00 \pm 0.03$ & 3.07 & $4.1(0.7)$ \\
\hline Class II & 17 & 0.55 & $9.4 \pm 0.07$ & $-18.21 \pm 0.03$ & $-16.84 \pm 0.03$ & $-16.75 \pm 0.03$ & 3.08 & $4.4(0.7)$ \\
\hline Class III & 10 & 0.40 & $10.36 \pm 0.07$ & $-17.77 \pm 0.03$ & $-16.76 \pm 0.03$ & $-16.68 \pm 0.03$ & 4.01 & $4.5(0.8)$ \\
\hline \multicolumn{9}{|l|}{ GSANT } \\
\hline Class I & 14 & 0.24 & $9.08 \pm 0.42$ & $-18.27 \pm 0.19$ & $-16.90 \pm 0.19$ & $-16.80 \pm 0.18$ & 3.07 & $3.9(0.7)$ \\
\hline Class II & 17 & 0.57 & $9.42 \pm 0.07$ & $-18.11 \pm 0.03$ & $-16.74 \pm 0.03$ & $-16.65 \pm 0.03$ & 3.08 & $4.4(0.7)$ \\
\hline Class III & 10 & 0,04 & $10.39 \pm 0.07$ & $-17.67 \pm 0.03$ & $-16.30 \pm 0.26$ & $-16.23 \pm 0.25$ & 4.01 & $4.5(0.8)$ \\
\hline
\end{tabular}

in the interaction between Trawl and Size (Table 4). $\delta^{13} \mathrm{C}$ values increased (i.e. were more enriched) with size at GCAST, while $\delta^{13} \mathrm{C}$ values were significantly more enriched in medium and large individuals than in juveniles at GTERM and GSANT (Table 4). The same output was obtained when one-way PERMANOVA was run with $\delta^{13} C_{\text {lipidfree }}$ values (results not displayed).

\section{Mixing models}

Mixing polygons were established for each gulf and size class by plotting the $\delta^{13} \mathrm{C}_{\text {lipidfree }}(1 \%$ fractionation assumed) and $\delta^{15} \mathrm{~N}$ values (3\%o fractionation-corrected) of potential dietary components. The results from the mixing model agree fairly well with the stomach content data for each size class in each area (Table 5), although marked differences occur regarding the contribution that each prey gives to the predator diet. The results of the mixing models concentrate on diet components that showed the most constrained solutions. In general class I hake relied on suprabenthic/planktonic resources. In GCAST they used small amphipods (such as Ampelisca spp., $21 \%$ ) euphausiids (31\%) and pandalids (38\%); in GTERM, they used mainly copepods $(42 \%)$ and $A l$ pheus glaber (42\%); in GSANT they used A. glaber (23\%), pandalids (49\%), euphausiids (21\%) and mysids $(10 \%)$. Class II hake still consumed pandalids (13\% in GTERM, 23\% in GCAST and $15 \%$ in GSANT) and A. glaber (13\% in GSANT and $16 \%$ in GCAST), but they also relied on fish. In GTERM gobiids were the main contributors to the diet $(76 \%)$, while in GCAST and GSANT hake preyed on clupeoids (31\% and 20\%, respectively) and Cepola macrophthalma (20\% at both locations). Class III hake fed on pandalids and A. glaber, although in a lower amount. Clupeoids constituted about $30 \%$ of the diet, together with C. macrophthalma ( $\mathrm{ca} .25 \%$ at GCAST and GSANT), gadids (22\% in GTERM and $15 \%$ in GCAST) and Serranus hepatus (19\% in GTERM and $22 \%$ at GSANT).
TABLE 4. - Results of univariate PERMANOVA based on the Euclidean distance of untransformed $\delta^{15} \mathrm{~N}$ and $\delta^{13} \mathrm{C}$ data of hake for each area and size class, based on the sampling design illustrated in the text (by 9999 permutations). *, $P<0.05$; **, $P<0.01$; n.s., not significant; I, size class I (60-120 mm TL); II, size class II (121-220 mm TL); III, size class III (221-410 mm TL).

\begin{tabular}{lcccccc}
\hline Source & $\begin{array}{c}\delta^{15} \mathrm{~N} \\
\text { df }\end{array}$ & MS & Pseudo- $F$ & $\begin{array}{c}\delta^{13} \mathrm{C} \\
\text { df }\end{array}$ & MS & Pseudo- $F$ \\
\hline Trawl & 1 & 0.04 & $0.50^{\mathrm{ns}}$ & 1 & 3.63 & $12.35^{\mathrm{ns}}$ \\
Size & 2 & 3.83 & $221.61^{* *}$ & 2 & 3.02 & $55.95^{*}$ \\
Gulf (Trawl) & 1 & 0.09 & $1.16^{\mathrm{ns}}$ & 1 & 0.29 & $9.23^{* *}$ \\
Trawl×Size & 2 & 0.01 & $0.57^{\mathrm{ns}}$ & 2 & 1.17 & $21.79^{*}$ \\
Gulf (Trawl) $\times$ size & 2 & 0.02 & $0.23^{\mathrm{ns}}$ & 2 & 0.05 & $1.69^{\mathrm{ns}}$ \\
Residuals & 18 & 0.07 & & 18 & 0.03 & \\
Total & 26 & & & 26 & &
\end{tabular}

Pairwise test on factor Size $\mathrm{I}<\mathrm{II}<\mathrm{III}$

Pairwise test on factor Size

$\mathrm{I}<\mathrm{II}=$ III

Pairwise test on the interaction

Trawl $\times$ Size for pairs of factor Size: within UTr: I $<$ II $<$ III within Tr: I=II=III

\section{DISCUSSION}

\section{Density and population structure}

The overall abundance of hake in the untrawled area was seven times higher than that in the trawled gulfs. Fewer fish in GTERM and GSANT is an expected result, given the importance of hake as a target commercial species, a fact that is also reflected in its declining abundance in Mediterranean fisheries (Fiorentini et al. 1997).

Comparison of length-frequency distribution and density data between size classes clearly highlighted the effect of protection on the hake population in GCAST. Smaller size classes ranging from 50 to 130 mm TL were more abundant in GCAST than in the trawled gulfs, although the differences were not significant because of high among-haul variance (Fanelli et al. 2010). In this case, the reduced fishing mortality in the untrawled area might have increased the recruitment rate of the hake population, as has been observed for the common pandora (Pagellus erythrinus) (Fanelli 
TABLE 5. - Mixing model results for each size class of hake in each gulf based on $\delta^{13} \mathrm{C}_{\text {lipidfree }}$ and $\delta^{15} \mathrm{~N}$. Class I, hake 60-120 mm TL; Class II, hake 121-220 mm TL; Class III, hake 221-410 mm TL; GCAST, Gulf of Castellammare; GTERM, Gulf of Termini Imerese; GSANT, Gulf of Sant'Agata.

\begin{tabular}{|c|c|c|c|c|c|c|c|c|c|c|}
\hline \multirow[b]{2}{*}{ source } & \multirow[b]{2}{*}{ area } & \multicolumn{3}{|c|}{ Class I } & \multicolumn{3}{|c|}{ Class II } & \multicolumn{3}{|c|}{ Class III } \\
\hline & & mean & SD & 1-99 percentile & mean & SD & 1-99 percentile & mean & SD & 1-99 percentile \\
\hline \multirow[t]{3}{*}{ Copepoda } & GCAST & 0.077 & 0.05 & $0-0.25$ & & & & & & \\
\hline & GTERM & 0.029 & 0.025 & $0-0.09$ & & & & & & \\
\hline & GSANT & 0.05 & 0.044 & $0-0.18$ & & & & & & \\
\hline \multirow[t]{2}{*}{ Euphausiacea } & $\begin{array}{l}\text { GCAST } \\
\text { GTERM }\end{array}$ & 0.162 & 0.172 & $0-0.52$ & 0.163 & 0.13 & $0-0.52$ & & & \\
\hline & GSANT & 0.114 & 0.094 & $0-0.38$ & & & & 0.082 & 0.059 & $0-0.24$ \\
\hline \multirow[t]{3}{*}{ Mysidacea } & GCAST & 0.077 & 0.057 & $0-0.26$ & & & & & & \\
\hline & GTERM & 0.029 & 0.025 & $0-0.09$ & & & & & & \\
\hline & GSANT & 0.048 & 0.041 & $0-0.16$ & & & & & & \\
\hline \multirow[t]{3}{*}{ Pandalidae } & GCAST & 0.411 & 0.12 & $0.26-0.50$ & 0.16 & 0.112 & $0-0.46$ & 0.117 & 0.116 & $0-0.47$ \\
\hline & GTERM & 0.418 & 0.131 & $0.15-0.62$ & 0.135 & 0.069 & $0-0.19$ & 0.111 & 0.079 & $0-0.33$ \\
\hline & GSANT & 0.457 & 0.091 & $0.27-0.64$ & 0.091 & 0.074 & $0-0.30$ & 0.128 & 0.086 & $0-0.35$ \\
\hline \multirow[t]{3}{*}{ A. glaber } & GCAST & 0.07 & 0.047 & $0-0.23$ & 0.109 & 0.076 & $0-0.31$ & 0.153 & 0.096 & $0-0.38$ \\
\hline & GTERM & 0.332 & 0.23 & $0-0.80$ & 0.042 & 0.03 & $0-0.03$ & 0.172 & 0.099 & $0-0.39$ \\
\hline & GSANT & 0.202 & 0.101 & $0-0.42$ & 0.078 & 0.062 & $0-0.25$ & 0.088 & 0.065 & $0-0.25$ \\
\hline \multirow[t]{3}{*}{ Ampelisca spp. } & GCAST & 0.202 & 0.019 & $0.16-0.25$ & 0.05 & 0.04 & $0-0.14$ & & & \\
\hline & GTERM & 0.171 & 0.087 & $0-0.01$ & 0.002 & 0.004 & $0-0.01$ & & & \\
\hline & GSANT & 0.077 & 0.059 & $0-0.22$ & 0.197 & 0.046 & $0.11-0.31$ & & & \\
\hline \multirow[t]{3}{*}{ L. sueri } & GCAST & & & & & & & 0.095 & 0.061 & $0-0.25$ \\
\hline & GTERM & & & & & & & & & \\
\hline & GSANT & & & & & & & & & \\
\hline \multirow[t]{2}{*}{ C. macrophthalma } & $\begin{array}{l}\text { GCAST } \\
\text { GTERM }\end{array}$ & & & & 0.014 & 0.012 & $0-0.04$ & 0.151 & 0.116 & $0-0.47$ \\
\hline & GSANT & & & & 0.166 & 0.098 & $0-0.4$ & 0.196 & 0.13 & $0-0.50$ \\
\hline \multirow[t]{3}{*}{ E. encrasicolus } & GCAST & & & & 0.258 & 0.17 & $0-0.66$ & 0.193 & 0.157 & $0-0.64$ \\
\hline & GTERM & & & & 0.011 & 0.01 & $0-0.03$ & 0.165 & 0.113 & $0-0.44$ \\
\hline & GSANT & & & & 0.197 & 0.154 & $0-0.60$ & 0.172 & 0.139 & $0-0.56$ \\
\hline \multirow[t]{3}{*}{ S. pilchardus } & GCAST & & & & 0.247 & 0.185 & $0-0.73$ & 0.189 & 0.135 & $0-0.53$ \\
\hline & GTERM & & & & 0.011 & 0.01 & $0-0.03$ & 0.211 & 0.151 & $0-0.57$ \\
\hline & GSANT & & & & 0.137 & 0.11 & $0-0.45$ & 0.136 & 0.107 & $0-0.63$ \\
\hline \multirow[t]{3}{*}{ Gadidae } & GCAST & & & & & & & 0.101 & 0.073 & $0-0.29$ \\
\hline & GTERM & & & & 0.018 & 0.022 & $0-0.06$ & 0.142 & 0.107 & $0-0.43$ \\
\hline & GSANT & & & & & & & & & \\
\hline \multirow[t]{3}{*}{ Gobiidae } & GCAST & & & & & & & & & \\
\hline & GTERM & & & & 0.682 & 0.057 & $0.65-0.87$ & 0.079 & 0.055 & $0-0.22$ \\
\hline & GSANT & 0.052 & 0.044 & $0-0.18$ & 0.135 & 0.111 & $0-0.45$ & & & \\
\hline \multirow[t]{3}{*}{ Serranus spp. } & GCAST & & & & & & & & & \\
\hline & GTERM & & & & & & & 0.121 & 0.093 & $0-0.37$ \\
\hline & GSANT & & & & & & & 0.198 & 0.108 & $0-0.44$ \\
\hline
\end{tabular}

et al. 2010) and for red mullet (Mullus barbatus) (Fiorentino et al. 2008). Also, the higher density of larger specimens in GCAST agrees with previous findings on fish stock recovery after a trawling ban (Piet and Rijnsdorp 1998, Pipitone et al. 2000, Jaworski et al. 2006).

\section{Diet composition}

Our results on stomach content analysis confirmed that hake is an active predator of motile fish and crustaceans (Carpentieri et al. 2005, Bozzano et al. 2005, Cartes et al. 2004, 2009). This study is also consistent with previous observations on the feeding habits of hake, which indicated a mixed diet based on pelagic as well benthic organisms (Bozzano et al. 2005, Carpentieri et al. 2005) and highlighted ontogenetic changes in the diet of hake, which cause a change in trophic level during ontogenetic development. Sizerelated changes in the diet are also important for other species of the genus Merluccius (Macpherson and Roel 1987).
The diet of hake shifted from euphausiids, consumed by smaller individuals, to a dominance of fish consumed by larger hake. Medium-sized individuals showed more generalized feeding habits, with a dominance of benthic and nektonic decapods and fish. These differences may be associated with different spatial distribution or genetic needs (Jukic and Arneri 1984, Velasco and Olaso 1998). The main prey of smaller hake, namely the euphausiid Nyctiphanes couchii (Fanelli, pers. observ.), is a school-forming planktonic crustacean that carries out vertical migrations (Casanova 1970, Franqueville 1971; Vallet and Dauvin, 2001), rising towards the surface at night to feed on phytoplankton and sinking deeper during daylight (Buchholz et al. 1995). Juvenile hake may follow such migrations, moving from near the bottom to midwater at night (Froglia 1973, Papaconstantinou and Caragitsou 1987, Orsi Relini et al. 1997). Oblique displacements of medium- and large-sized hakes were suggested by Cartes et al. (2004) to be explained by feeding on the benthopelagic shrimp $C$. crassicornis, which was found in hake stomachs and was distributed 
deeper than hake in daylight samplings. Finally, the shift to an ichthyophagous diet observed in this study in medium- to large-sized individuals might be related to a change in trophic requirements, that is, an increase in energy demands for gonad development (Ross 1978, Carpentieri et al. 2005).

\section{Spatial variation in diet composition according to size class}

Important variations in the feeding habits of hake among the three gulfs were recorded in this study. Differences mostly concerned medium- and largesized specimens, the diet of juveniles being more homogeneous in the three areas. While the diet of class II-III hake in the trawled gulfs was more generalist, with a large proportion of decapods and of nektobenthic and pelagic fish, in the untrawled area hake consumed mainly pelagic fish, especially $S$. pilchar$d u s$. It is well know that the abundance of clupeoids depends on seasonal primary production as well as on local oceanographic features that may enrich water trophism (Palomera et al. 2007). Unfortunately, no data on the abundance of clupeoids in the study area were available for the study period. Moreover, all gulfs had a similar trophic condition (Fanelli et al. 2011) and all fish samplings were made in the same month, so other unknown factors might explain the higher feeding pressure of hake on small pelagic fish in GCAST. Two hypotheses may be formulated on this finding. First, an exceptionally high abundance of clupeoids in the area in 2005 (partially confirmed by stable isotopes analysis, see below) and, second, a stronger intra- and interspecific competition for food in the untrawled area due to higher abundance of fish, which pushes hake to exploit different-usually less used-resources (pelagic fish in this case). As a consequence of the long-lasting trawl ban (15 years at the time of sampling) the abundance of hake and many other demersal fish in GCAST, including benthic predators such as red mullet and pandora, is considerably higher than in the trawled gulfs (Badalamenti et al. 2008, this study). This may have led to increased interspecific competition for resources, as observed in other untrawled areas (McClanahan et al. 2007), and to stronger intraspecific competition, as evidenced by CCA analysis. Instead, in the plot some points belonging to class III hake from GCAST were allocated in the area of clupeoid prey while others were allocated in the area of benthic and benthopelagic prey.

\section{Comparison between ecological categories and niche breadth}

Grouping species on the base of ecological categories is a procedure widely used for a better understanding of functional processes in natural systems (Root 1967, Hajisamae 2003, Koslow 1997, Cartes et al. 2002, Auster and Link 2009). In the Mediterranean, feeding guilds were successfully used to investigate the trophic patterns of different ecosystems (Cartes et al. 2002), and used in the continental shelf of the NW Atlantic to assess functional changes in the food web structure (Auster and Link 2009). Generally, the interpretation of data grouped in categories has the main objective of reducing complexity and identifying general patterns. According to our results, ecological categories helped to emphasize diet differences among gulfs, particularly for medium- and large-sized hake. Individuals of class II from trawled gulfs fed on short life span benthic carnivores (mainly benthic decapods) more than those in the untrawled gulf. This is in agreement with the higher abundance of decapod crustaceans (mainly represented by the penaeid shrimp Parapenaeus longirostris) recorded in the trawled gulfs (Badalamenti et al. 2007) and with their generally higher density in heavily trawled areas than in less fished areas (Demestre et al. 2008, Carpentieri et al. 2005).

The higher proportion of long life span benthic carnivores (mainly composed of fish) in the diet of class II-III hake from GSANT was surprising, considering the high trawl intensity in this area. About 50\% of this category was represented by the gobiid fish L. suerii, a small, highly motile burrowing predator. This species is among the preferential preys for adult scaldfish (Arnoglossus laterna) and common pandora (P. erythrinus) in GTERM and GSANT (Fanelli et al. 2009b, Fanelli et al. 2010) and it is hardly affected by trawling (de Juan et al. 2007). Indeed, this small fish is more abundant in both trawled gulfs (1.4 ind./100 $\mathrm{m}^{2}$ in samples collected with a Macer-GIROQ sledge) than in the untrawled gulf $\left(0.3\right.$ ind.$/ 100 \mathrm{~m}^{2}$; Fanelli et al. 2010), and is also abundant in trawling grounds of the Catalan Sea (de Juan et al. 2007a), probably indicating that it is able to avoid the direct impact of trawl nets to some extent. With regard to the high abundance of suprabenthic suspension-deposit feeders in GTERM, it has been demonstrated (Cartes et al. 2007, Fanelli et al. 2011a, Ligas et al. 2009) that suprabenthos is hardly affected by trawling. Thus, it is reasonable that in the absence of more energetic benthic pelagic prey in GTERM, hake feed mainly on suprabenthic resources.

\section{The effect of the trawl ban on the isotopic composition and trophic level of hake}

Stable isotope analysis only partially confirmed the results obtained from stomach content analysis. $\delta^{15} \mathrm{~N}$ values were similar for the three size classes in the three gulfs, with no significant differences between trawled and untrawled gulfs. A similar result was found by Badalamenti et al. (2008), who detected a significant difference only in one limited geographic sector, where $\delta^{15} \mathrm{~N}$ was higher in GCAST. In general $\delta^{15} \mathrm{~N}$ values were typical of a species feeding on benthopelagic resources, which normally did not display high $\delta^{15} \mathrm{~N}$ values, unlike benthic predators (i.e. red mullet, 
Badalamenti et al. 2008; common pandora, Fanelli et al. 2010).

Conversely, $\delta^{13} \mathrm{C}$ values were generally more depleted (from $-19.9 \%$ o in smaller hake to $-18.4 \%$ o in larger hake) in the untrawled area than in the trawled areas (from $-18.5 \%$ o to $17.7 \%$ ), according to higher consumption of pelagic prey in GCAST (euphausiids and mysids in small hake, clupeoids in larger ones), which displayed more depleted $\delta^{13} \mathrm{C}$ values (Pinnegar and Polunin 2000, Fanelli et al. 2009a, 2011a, 2011b).

In agreement with Badalamenti et al. (2002), $\delta^{15} \mathrm{~N}$ values increased with size in all gulfs. This is consistent with the dietary ontogenetic shift observed for this species through stomach content analysis (Carpentieri et al. 2005; this study): smaller hake preyed mainly upon euphausiids and mysids (mean $\delta^{15} \mathrm{~N}$ from $4.2 \%$ to 6.5\%o, Fanelli et al. 2009a, 2011a), while larger individuals preyed upon fish, mainly clupeoids (mean $\delta^{15} \mathrm{~N}$ from $7.2 \%$ to $7.8 \%$ : unpublished data).

The trophic level of hake calculated with TrophLab displayed higher values than those obtained from stable isotope analysis. This may be attributed to the fact that TrophLab assigns a high trophic level to fish prey regardless of their habitat and hence of their diet (i.e. benthic or pelagic). Badalamenti et al. (2002, 2008) and Fanelli et al. (2010) demonstrated that in littoral systems the trophic level of benthic fish such as red mullet and common pandora, which prey upon carnivore polychaetes, is close to that of larger piscivorous predators. Conversely, pelagic food webs are relatively simple (Bode et al. 2007, Fanelli et al., 2011b) and small pelagic fish such as clupeoids, feeding on zooplankton, exhibit lower $\delta^{15} \mathrm{~N}$ values than fish from benthic and suprabenthic assemblages that belong to more complex food webs organized into at least three trophic levels (from deposit feeders to carnivores: Carlier et al. 2007, Fanelli et al. 2009a, 2011c), with small fish occupying the same trophic level as carnivorous polychaetes or small decapods.

Mixing models, carried out on stable isotope data for the main potential food sources, indicated mysids, euphausiids and pandalids as a major food source for smaller hake in the three areas, while A. glaber dominated their diet in GTERM and GSANT, according to their higher abundance in the two trawled gulfs (Fanelli et al. 2010). Conversely, the small amphipod Ampelisca sp., which is a filter/suspension feeder (Scipione 1989) more susceptible to trawling activities and consequently more abundant in the untrawled gulf, was confirmed as a major prey item for juvenile hake in GCAST.

Clupeoids (S. pilchardus, S. aurita and E. enchrasicolus) were mainly consumed by medium-sized hake at GCAST and GSANT. However, unlike the results of stomach content analysis for GCAST, other prey such as pandalid shrimps and A. glaber seemed to be important in the mixing model output. Thus, the high consumption of clupeoids observed in the diet of medium-sized individuals in GCAST seems to be a "snapshot" of hake diet in time and space (Polunin and Pinnegar 2002) due to the high abundance of such small pelagic fish in late spring-early summer (Basilone et al. 2004) rather than a time-integrated vision of the diet over a larger period, as offered by stable isotopes analysis, which is much less subject to seasonal bias. Finally, predation by larger hake on clupeoids suggested by the mixing model was as high in GCAST as in the trawled areas, again in contrast with the results of stomach content analysis, which highlighted an almost exclusive consumption of $S$. pilchardus in GCAST. This inconsistency could be due to a different seasonal abundance peak of clupeoids in the three areas as a consequence of different peaks in the primary production, which occurred in February 2005 in GCAST and in January 2005 in the other two gulfs (data source: http://reason.gsfc.nasa. gov), with possible temporal differences in the peak availability of clupeoid prey in the three areas.

\section{CONCLUSIONS}

This study confirms previous findings on the feeding habits and ontogenetic shift in the diet of hake. In this study we have investigated the possible diet variations in areas subject to different fishing pressure. Although some significant differences between untrawled and trawled areas were found in the diet of medium- and large-size hake, which are the size classes most affected by trawling activity because of their higher catchability, it is difficult to attribute these differences directly to the effect of the trawl ban in GCAST. The initial hypothesis formulated for class II hake may be accepted, since it appeared that nektobenthic crustaceans, abundant in the diet of specimens from trawled areas, were favoured by trawling activity. Conversely, it is hard to demonstrate the hypothesis formulated for class III and further study, encompassing temporal replicates of both stomach content and stable isotope analyses, is therefore required. Finally, while abundance and population structure of hake are clearly related to trawling disturbance, the analysis of diet and trophic level seemed to be less effective in assessing the effect of fishery pressure on this species.

\section{ACKNOWLEDGEMENTS}

Samples were collected under Project No. 6A84/2003 funded by the Italian Ministry of Agriculture and Forests. The authors wish to thank all the participants in the field work, the technical staff at CNRIAMC in Castellammare del Golfo, and Dr Valentina Lauria, who helped with stomach content analysis. Special thanks go to Drs. P. Rumolo (CNR-IAMC, Capo Granitola, IT), C. Sweeting (CEFAS, Newcastle, UK) and S. Vizzini (University of Palermo, IT) for isotope analysis. 


\section{REFERENCES}

Anderson M.J. 2001. A new method for non-parametric multivariate analysis of variance. Austral. Ecol. 26: 32-46.

Anderson M.J ,Willis T.J. 2003. Canonical analysis of principal coordinates: a useful method of constrained ordination for ecology. Ecology 84: 511-524.

Auster P.J., Link J.S. 2009. Compensation and recovery of feeding guilds in a northwest Atlantic shelf fish community. Mar. Ecol. Prog. Ser. 382: 163-172.

Badalamenti F., D’Anna G., Pinnegar J.K., Polunin N.V.C. 2002. Size-related trophodynamic changes in three target fish species recovering from intensive trawling. Mar. Biol. 141: 561-570.

Badalamenti F., D’Anna G., Pipitone C. 2007. Ricostituzione delle risorse di pesca in un' area precedentemente soggetta ad intenso sfruttamento: dinamiche a larga scala del popolamento ittico e della struttura trofica della comunità marina. Relazione finale del progetto n. 63. Ministero dell'Istruzione, dell'Università e della Ricerca, 247 pp.

Badalamenti F., Sweeting C.J., Polunin N.V.C, Pinnegar J.K., D’Anna G., Pipitone C. 2008. Limited trophodynamics effects of trawling on three Mediterranean fishes. Mar. Biol. 154: 765-773.

Basilone G., Guisande C., Patti B., Mazzola S., Cuttitta A., Bonanno A., Kallianiotis A. 2004. Linking habitat conditions and growth in the European anchovy (Engraulis encrasicolus). Fish. Res. 68: $9-19$.

Bianchi G., Gislason H., Graham K., Hill L., Jin X., Koranteng K., Manickchand-Heileman S., Paya I., Sainsbury K., Sanchez F., Zwanenburg K. 2000. Impact of fishing on size composition and diversity of demersal fish communities. ICES J. Mar. Sci. 57: 558-571.

Bode A., Alvarez-Ossorio M.T., Cunha M.E., Garrido S., Peleteiro J.B., Porteiro C., Valdés L., Varela M. 2007. Stable nitrogen isotope studies of the pelagic food web on the Atlantic shelf of the Iberian Peninsula. Prog. Ocean. 74: 115-131.

Bozzano A., Sarda F., Rios J. 2005. Vertical distribution and feeding patterns of the juvenile European hake, Merluccius merluccius in the NW Mediterranean. Fish. Res. 73: 29-36.

Carlier A., Riera P., Amouroux J-M., Bodiou J-Y., Grémare A. 2007. Benthic trophic network in the Bay of Banyuls-sur-Mer (northwest Mediterranean, France): an assessment based on stable carbon and nitrogen isotopes analysis. Estuar. Coast. Mar. Sci. 72: 1-15.

Carpentieri P., Colloca F., Cardinale M., Belluscio A., Ardizzone G.D. 2005. Feeding habits of European hake (Merluccius merluccius) in the central Mediterranean Sea. Fish. Bull. 103: 411-416.

Cartes J.E., Abelló P., Lloris D., Carbonell A., Torres P., Maynou F., Gil de Sola L. 2002. Analysis of feeding guilds of fish and decapod crustaceans during the MEDITS-99 cruise along the Iberian Peninsula Mediterranean coasts. Sci. Mar. 66(2): 209-220.

Cartes J.E., Rey J., Lloris D., Gil de Sola L. 2004. Influence of environmental variables on the feeding and diet of European hake (Merluccius merluccius) on the Mediterranean Iberian coasts. J. Mar. Biol. Ass. U. K. 84: 831-835.

Cartes J.E., Hidalgo M., Papiol V., Massutí E., Moranta J. 2009. Changes in the diet and feeding of the hake Merluccius merluccius at the shelf-break of the Balearic Islands: influence of the mesopelagic-boundary community. Deep-Sea. Res. 56: 344-365.

Casanova B. 1970. Répartition bathymétrique des euphausiacés dans le bassin occidental de la Méditerranée. Rev. Trav. Inst. Pêches. Marit. 34(2): 205-219.

De Juan S., Thrush S., Demestre M. 2007. Functional changes as indicator of trawling disturbance on a benthic community from a fishing ground (NW Mediterranean). Mar. Ecol. Prog. Ser. 334: 117-129.

De Juan S., Cartes J.E., Demestre M. 2007. Effects of commercial trawling activities in the diet of the flat fish Citharus linguatula (Osteichthyes: Pleuronectiformes) and the starfish Astropecten irregularis (Echinodermata: Asteroidea). J. Exp. Mar. Biol. Ecol. 349: 152-169.

Demestre M., de Juan S., Sartor P., Ligas A. 2008. Seasonal closures as a measure of trawling effort control in two Mediter- ranean trawling grounds: Effects on epibenthic communities. Mar. Pollut. Bull. 56(10): 1765-1773.

Engel J., Kvitek R. 1998. Effects of otter trawling on a benthic community in Monterey Bay National Marine Sanctuary. Conserv. Biol. 12: 1204-1214.

Fanelli E., Cartes J.E., Badalamenti F., Rumolo P., Sprovieri M. 2009a. Trophodynamics of suprabenthic fauna on coastal muddy bottoms of southern Tyrrhenian Sea (western Mediterranean). J. Sea Res. 61(3): 174-187.

Fanelli E., Badalamenti F., D'Anna G., Pipitone P. 2009b. Diet and trophic level of the scaldfish Arnoglossus laterna in southern Tyrrhenian Sea (western Mediterranean): contrasting trawled vs. untrawled areas. J. Mar. Biol. Ass. U.K. 89(4): 817-828.

Fanelli E., Badalamenti F., D’Anna G., Pipitone P., Romano C. 2010. Trophodynamic effects of trawling on the feeding ecology of pandora, Pagellus erythrinus off the northern Sicily coast (Mediterranean Sea). Mar. Freshwater. Res. 61: 408-417.

Fanelli E., Cartes J., Badalamenti F., D’Anna G., Pipitone C. Azzurro E., Rumolo P., Sprovieri M. 2011a. Meso-scale spatial variations of coastal suprabenthic communities off Northern Sicily (Central Mediterranean). Estuar. Coastl. Shelf Sci. 91: 351-360.

Fanelli E., Cartes J.E., Papiol V. 2011b. Trophodynamics of zooplankton fauna on the Catalan slope (NW Mediterranean): insight from $\delta^{13} \mathrm{C}$ and $\delta^{15} \mathrm{~N}$ analysis. J. Mar. Syst. 87: 79-89.

Fanelli E., Papiol V., Cartes J.E., Rumolo P., Brunet C., Sprovieri M. 2011c. Food web structure of the megabenthic, invertebrate epifauna on the Catalan slope (NW Mediterranean): evidence from $\delta^{13} \mathrm{C}$ and $\delta^{15} \mathrm{~N}$ analysis. Deep-sea Res. 58: 98-109.

FAO. 2005. Review of the state of world marine fishery resources. FAO. Fish. Tech. Pap., 457: 235 pp.

Fiorentini L., Caddy J.F., De Leiva J.I. 1997. Long and short-term trends of Mediterranean fishery resources. Studies and Reviews. GFCM, No. 69. FAO, Rome.

Fiorentino F., Badalamenti F., D’Anna G., Garofalo G., Gianguzza P., Gristina M., Pipitone C., Rizzo P., Fortibuoni T.2008. Changes in spawning-stock structure and recruitment pattern of red m.ullet, Mullus barbatus, after a trawl ban in the Gulf of Castellammare (central Mediterranean Sea). ICES J. Mar. Sci. 65:1175-1183.

Franqueville C. 1971. Macroplancton profond (invertébrés) de la Méditerranée nord-occidentale. Tethys 3(1): 11-56.

Froglia C. 1973. Osservazioni sull'alimentazione del merluzzo (Merluccius merluccius L.) del Medio Adriatico. In: N. Salentina, (ed) Atti V Congresso Naz. Soc. It. Biol. Mar. 327-341.

Gibson R. N. Ezzi I.V.1987. Feeding relationships of a demersal fish assemblage on the west coast of Scotland. J. Fish. Biol. 31: 55-69.

Graham N.A.J., Evans R.D., Russ G.R. 2003.The effects of marine reserve protection on trophic relationships of reef fishes on the Great Barrier Reef. Environ. Conserv. 30(2): 200-208.

Greco S. 1994. Considerazioni sullo stato di sfruttamento delle risorse demersali (Capo Suvero-San Vito Lo Capo). Biol. Mar. Med. 1: 61-66.

Greenstreet S.P.R., Hall S.J. 1996. Fishing and the ground-fish assemblage structure in the north-western North Sea: an analysis of long-term and spatial trends. J. Anim. Ecol. 65: 577-598.

Hajisamae S., Choua L.M., Ibrahimb S. 2003. Feeding habits and trophic organization of the fish community in shallow waters of an impacted tropical habitat. Estuar. Coast. Shelf Sci. 58: 89-98.

Hiddink J.G., Rijnsdorp A., Piet G. 2008. Can bottom trawling disturbance increase food production for a commercial fish species? Can. J. Fish. Aq. Sci. 65: 1393-1401.

Hyslop E.P. 1980. Stomach contents analysis, a review of methods and their application. J. Fish Biol. 17: 411-429.

Jennings S., Renones O., Morales-Nin B., Polunin N.V.C., Moranta J., Coll J. 1997. Spatial variation in the ${ }^{15} \mathrm{~N}$ and ${ }^{13} \mathrm{C}$ stable isotope composition of plants. invertebrates and fishes on Mediterranean reefs: Implications for the study of trophic pathways. Mar. Ecol. Prog. Ser. 146: 109-116.

Jennings S., Kaiser M.J. 1998. The effects of fishing on marine ecosystems. Adv. Mar. Biol. 34: 201-352.

Jennings S., Kaiser M.J, Reynolds J.D. 2001a. Marine fisheries ecology. Blackwell Science. London, 417 pp.

Jennings S., Pinnegar J.K., Polunin N.V.C., Boon T.W. 2001 b. Weak cross-species relationships between body size and trophic level belie powerful size-based trophic structuring in fish com- 
munities. J. Anim Ecol. 70: 934-944

Jennings S., Pinnegar J.K., Polunin N.V.C, Warr K.J. 2001c. Impacts of trawling disturbance on the trophic structure of benthic invertebrate communities. Mar. Ecol. Prog. Ser. 213: 127-142.

Jennings S., Greenstreet S.P.R., Hill L, Piet G.J., Pinnegar J.K. Warr K.J. 2002a. Long-term trends in the trophic structure of the North Sea fish community: evidence from stable-isotope analysis. size-spectra and community metrics. Mar. Biol. 141 1085-1097.

Jennings S., Pinnegar J.K, Polunin N.V.C, Warr K.J. 2002b. Linking size-based and trophic analyses of benthic community structure. Mar. Ecol. Progr. Ser. 226: 77-85.

Jennings S., Mackinson S. 2003. Abundance-body mass relationships in size-structured food webs. Ecol. Lett. 6: 971-974.

Jukic S., Arneri E. 1984. Distribution of hake (Merluccius merluccius, L.) striped mullet (Mullus barbatus, L.) and pandora (Pagellus erythrinus, L.) in the Adriatic Sea. FAO Fish. Rep. 290: 85-91.

Kiljunen M, Grey J, Sinisalo T, Harrod C, Immonen H, Jones, R.I. 2006. A revised model for lipid-normalising d13C values from aquatic organisms, with implications for isotope mixing models. J. Appl. Ecol. 43, 1213-1222.

Kaiser M.J., Spencer B.E. 1994. Fish scavenging behaviour in recently trawled areas. Mar. Ecol. Prog. Ser. 112: 41-49.

Koslow J.A. 1997. Seamounts and the ecology of deep-sea fisheries. Am. Sci. 85:168-176.

Krebs C.J. 1989. Ecological methodology. Harper and Row. New York, $654 \mathrm{pp}$.

Ligas A., De Biasi A.M., Demestre M., Pacciardi L., Sartor P., Cartes J.E. 2009. Effects of chronic trawling disturbance on the secondary production of suprabenthic and infaunal crustacean communities in the Adriatic Sea (NW Mediterranean). Cienc. Mar. 35(2): 195-207.

Lloris D., Matallanas J., Oliver P. 2005. Species catalogue for fishery Purposes. Hakes of the World. FAO, Roma, $57 \mathrm{pp}$.

Logan J., Jardine T., Miller T., Bunn S., Cunjak R., Lutcavage M. 2008. Lipid corrections in carbon and nitrogen stable isotope analyses: comparison of chemical extraction and modelling methods. J. Anim. Ecol. 77: 838-846.

Macpherson E., Roel B. 1987. Trophic relationships in the demersal fish community of Namibia. In: Payne AI., Gulland J.A., Brink., KH. (eds.), The Benguela and Comparable Ecosystems. S. Afr. J. Mar. Sci. 5: 585-596.

Mc Connaughey T., McRoy C.P. 1979. Food-web structure and the fractionation of carbon isotopes in the Bering Sea. Mar. Biol. 53: $257-262$

Minagawa M., Wada E. 1984. Stepwise enrichment of ${ }^{15} \mathrm{~N}$ along food chains: further evidence and the relation between $\mathrm{d}^{15} \mathrm{~N}$ and animal age. Geochim. Cosmoch. Ac. 48: 1135-1140.

Modica L., Bozzano A., Velasco F. Albertelli G., Olaso I. 2011. Predation, feeding strategy and food daily ration in juvenile European hake. Mar. Ecol. Prog. Ser. 440: 177-189

Murawski S.A., Brown R., Lai H-L, Rago P. J., Hendrickson L. 2000. Large-scale closed areas as a fishery management tool in temperate marine ecosystems: the Georges Bank experience. Bull. Mar. Sci. 66: 775-798.

McClanahan T.R. 2007. Management of Area and Gear in Kenyan Coral Reefs. In: McClanahan T.R., Castilla J.C. (eds.), Fisheries Management: Progress Towards Sustainability, Blackwell Publishing Ltd. Oxford. pp 166-185.

Oliver P., Massutí E. 1995. Biology and fisheries of western Mediterranean hake (Merluccius merluccius). In: Alheit J., Pitcher T.J. (eds.), Hake: fisheries, ecology and markets. Chapman \& Hall, London, pp: 181-202.

Olsgard M.T., Schaanning S., Widdicombe M.A., Kendall M.A., Austen M.C. 2008. Effects of bottom trawling on ecosystem functioning. J. Exp. Mar. Biol. Ecol. 366: 123-133.

Orsi Relini L., Zamboni A., Fiorentino F., Relini G. 1997. Vulnerabilità luce-dipendente del nasello (Merluccius merluccius ) giovanile. Biol. Mar. Medit. 4: 262-268

Papaconstantinou C., Caragitsou E. 1987. The food of hake (Merluccius merluccius) in Greek Seas. Vie Milieu 37: 77-83.

Pauly D., Christensen V., Dalsgaard J., Froese R., Torres F. 1998. Fishing down marine food webs. Science 279: 860-863.
Pauly D., Christensen V., Froese R., Palomares M.L. 2000. Fishing down aquatic food webs. Am. Sci. 88: 46-51.

Palomera I., Olivar M.P., Salat J., Sabates A., Coll M., Garcia A., Morales-Nin B. 2007. Small pelagic fish in the NW Mediterranean Sea: An ecological review. Progr. Oceanogr. 74: 377-396.

Phillips D.L., Gregg. J.W. 2001. Uncertainty in source partitioning using stable isotopes. Oecologia 127: 171-179.

Phillips D.L., Gregg J.W. 2003. Source partitioning using stable isotopes: coping with too many sources. Oecologia 136: 26-269.

Pinkas L., Oliphant M.S., Iverson I.L.K. 1971. Food habits of albacore, bluefin tuna, and bonito in California waters. Fish. Bull. 152: $1-105$.

Pinnegar J.K., Polunin N.V.C. 2000. Contributions of stable-isotope data to elucidating food webs of Mediterranean rocky littoral fishes. Oecologia 122: 399-409.

Pipitone C., Badalamenti F., D'Anna G., Patti B. 2000. Fish biomass increase after a four-year trawl ban in the Gulf of Castellammare (NW Sicily. Mediterranean Sea). Fish. Res. 48: 23-30.

Polunin N.V.C, Pinnegar J.K. 2002. Trophic ecology and the structure of marine food webs. In: Hart P.J., Reynolds J.D. (eds.), Handbook of fish and fisheries. Blackwell Science, Oxford, pp. 301-320.

Post D.M. 2002. Using stable isotopes to estimate trophic position models, methods, and assumptions. Ecology 83: 703-718.

Relini G., Bertrand J., Zamboni A. (eds.) 1999. Sintesi delle conoscenze sulle risorse da pesca dei fondi del Mediterranmeo centrale (Italia e Corsica). Synthesis of the knowledge on bottom fishery resources in central Mediterranean (Italy and Corsica). SIBM, Genova: 868 pp.

Root R.B. 1967. The niche exploitation pattern of the blue-gray gnatcatcher. Ecol. Monogr. 37: 317-350.

Ross S.T. 1978. Trophic ontogeny of the leopard searobins, Prionotus scitulus (Pisces: Triglidae). Fish. Bull. 76: 225-234.

Sánchez Lizaso J.L., Goñi R., Reñones O., García Charton J.A., Galzin R., Bayle J.T., Sánchez Jerez P., Pérez Ruzafa A., Ramos A. 2000. Density dependence in marine protected populations: a review. Environ. Conser. 27: 144-158.

Sainte-Marie B., Brunel P. (1985). Suprabenthic gradients of swimming activity by cold-water gammaridean amphipod Crustacea over a muddy shelf in the Gulf of Saint Lawrence. Mar. Ecol. Prog. Ser. 23: 57-69.

Scipione M.B. 1989. Comportamento trofico dei Crostacei anfipodi in alcuni sistemi bentonici costieri. Oebalia 15(1):249-260.

Schindler D.E., Lubetkin S.C. 2004. Using stable isotopes to quantify material transport in food webs. In: Polis GA. Power M.E., Huxel G.R. (eds.), Food Webs at the Landscape Level. The University of Chicago Press, Chicago, pp. 25-42.

Schmidt-Nielsen K. 1984. Scaling: Why is animal size so important? Cambridge University Press. New York. $181 \mathrm{pp}$.

Schratzberger M., Jennings S. 2002. Impacts of chronic trawling disturbance on meiofaunal communities. Mar. Biol. 141: 991-1000.

Smith C.J., Papadopoulou K.N., Diliberto. S. 2000. Impact of otter trawling on an eastern Mediterranean commercial trawl fishing ground. ICES J. Mar. Sci. 57: 1340-1351.

St John J., Russ G.R., Brown I.W., Squire L.C. 2001. The diet of the large coral reef serranid Plectropomus leopardus in two fishing zones on the Great Barrier Reef. Australia. Fish. Bull. 99: 180-192.

Svanbäck R., Eklöv P., Fransson R., Holmgren K. 2008. Intraspecific competition drives multiple species resource polymorphism in fish communities. Oikos 117: 114-124.

Vallet C., Dauvin J.C. 2001. Biomass changes and bentho-pelagic transfers throughout the Benthic Boundary Layer in the English Channel. J. Plankton Res. 23(9): 903-922.

Velasco F., Olaso I. 1998. European hake Merluccius merluccius L., 1758 ) feeding in the Cantabrian Sea: seasonal, bathymetric and length variations. Fish. Res. 38: 33-44.

Ward A.J.W., Webster M.M., Hart P.J.B. 2006. Intraspecific food competition in fishes. Fish. Fish. 7: 231-261

Scient. ed.: E. Massutí.

Received January 11, 2012. Accepted September 17, 2012.

Published online October 29, 2012. 
$690 \cdot$ M. SINOPOLI et al.

APPENDIX 1. - List of the taxa found in stomach contents of hake in the Gulfs of Castellammare (GCAST), Termini Imerese (GTERM) and Sant'Agata (GSANT) in terms of per cent number $(\% \mathrm{~N})$ and per cent IRI (\%IRI). Class I, 60-120 mm TL; Class II, 121-220 mm TL; Class III, 221-410 mm TL.

\begin{tabular}{|c|c|c|c|c|c|c|c|c|c|c|c|c|c|c|c|c|c|c|}
\hline \multirow{3}{*}{$\begin{array}{l}\text { Area } \\
\text { Size } \\
\text { Taxon }\end{array}$} & \multicolumn{6}{|c|}{ GCAST } & \multicolumn{6}{|c|}{ GTERM } & \multicolumn{6}{|c|}{ GSANT } \\
\hline & \multicolumn{2}{|c|}{ Class I } & \multicolumn{2}{|c|}{ Class II } & \multicolumn{2}{|c|}{ Class III } & \multicolumn{2}{|c|}{ Class I } & \multicolumn{2}{|c|}{ Class II } & Clas & ss III & $\mathrm{Cl}$ & ass I & & lass II & $\mathrm{Cl}_{\mathrm{s}}$ & ass III \\
\hline & $\% \mathrm{~N}$ & $\%$ IRI & $\% \mathrm{~N}$ & $\%$ IRI & $\% \mathrm{~N}$ & $\%$ IRI & $\% \mathrm{~N}$ & $\%$ IRI & $\% \mathrm{~N}$ & $\%$ IRI & $\% \mathrm{~N}$ & $\%$ IRI & $\% \mathrm{~N}$ & $\%$ IRI & $\% \mathrm{~N}$ & $\%$ IRI & $\% \mathrm{~N}$ & $\%$ IRI \\
\hline CRUSTACEA & & & & & & & & & & & & & & & & & & \\
\hline Copepoda & & & & & & & & & & & & & & & & & & \\
\hline Calanoida & - & - & - & - & - & - & - & - & - & - & - & - & 2.94 & 0.68 & - & - & - & . \\
\hline Amphipoda & & & & & & & & & & & & & & & & & & \\
\hline Ampelisca tipica & - & - & - & - & - & - & - & - & 13.54 & 1.77 & - & - & 0.59 & 0.05 & - & - & - & - \\
\hline Monoculodes griseus & - & - & - & - & - & - & - & - & 1.04 & 0.14 & - & - & - & - & - & - & - & - \\
\hline Isopoda & & & & & & & & & & & & & & & & & & \\
\hline Rocinela dumerili & 2.33 & 0.32 & 3.85 & 0.54 & - & - & - & - & - & - & - & - & - & - & 2.00 & 0.30 & 3.51 & 0.78 \\
\hline Mysidacea & & & & & & & & & & & & & & & & & & \\
\hline Lophogaster typicus & 3.49 & 0.92 & - & - & - & - & 4.20 & 4.57 & 3.13 & 1.32 & - & - & 6.47 & 11.11 & - & - & - & - \\
\hline Mysidacea unid. & 11.63 & 3.88 & - & - & - & - & 1.40 & 0.45 & 1.04 & 0.14 & - & - & 0.59 & 0.04 & - & - & - & - \\
\hline Cumacea & & & & & & & & & & & & & & & & & & \\
\hline Dyastilis sp. & - & - & - & - & - & - & - & - & 1.04 & 0.14 & - & - & - & - & - & - & - & - \\
\hline Total Peracarida & 17.44 & 5.13 & 3.85 & 0.54 & - & - & 5.59 & 5.01 & 19.79 & 3.49 & - & - & 10.59 & 911.89 & 2.00 & 0.30 & 3.51 & 0.78 \\
\hline Euphausiacea & & & & & & & & & & & & & & & & & & \\
\hline Euphausiacea unid. & 58.14 & 57.88 & 3.85 & 0.54 & - & - & 70.63 & 53.72 & 21.88 & 5.71 & - & - & 62.94 & 446.91 & - & - & - & - \\
\hline Decapoda & & & & & & & & & & & & & & & & & & \\
\hline Larvae & - & - & - & - & - & - & - & - & - & - & - & - & 8.82 & 0.65 & - & - & - & 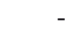 \\
\hline Adult & & & & & & & & & & & & & & & & & & \\
\hline Alpheus glaber & - & - & 1.92 & 0.15 & 1.02 & 0.05 & - & - & 1.04 & 0.15 & - & - & 0.59 & 0.08 & 6.00 & 1.82 & 1.75 & 0.21 \\
\hline Chlorotocus crassicornis & 3.49 & 3.02 & - & - & 5.10 & 1.23 & 1.40 & 1.17 & 6.25 & 4.16 & 6.25 & 1.42 & 2.35 & 3.30 & 16.00 & 16.15 & 7.02 & 3.31 \\
\hline Liocarcinus depurator & - & - & - & - & - & - & - & - & - & - & 6.25 & 1.46 & - & - & - & - & - & - \\
\hline Parapenaeus longirostris & - & - & - & - & - & - & - & - & - & - & - & - & 0.59 & 1.83 & - & - & - & - \\
\hline Pontocaris lacazei & - & - & - & - & - & - & 0.70 & 0.74 & 1.04 & 0.18 & - & - & 1.18 & 0.86 & 2.00 & 0.41 & 1.75 & 0.22 \\
\hline Processa sp. & - & - & - & - & 6.12 & 0.57 & 6.99 & 4.22 & 7.29 & 5.44 & - & - & 1.76 & 1.15 & 8.00 & 4.95 & 8.77 & 1.98 \\
\hline Scyllarus cfr arctus & - & - & - & - & - & - & - & - & 1.04 & 0.16 & - & - & - & - & - & - & - & - \\
\hline Solenocera membranacea & - & - & - & - & 3.06 & 0.50 & - & - & 1.04 & 0.32 & - & - & 0.59 & 0.40 & - & - & 3.51 & 0.82 \\
\hline Upogebia tipica & - & - & - & - & - & - & - & - & - & - & - & - & - & - & 2.00 & 0.32 & - & - \\
\hline Caridea & - & - & - & - & - & - & - & - & - & - & - & - & 0.59 & 0.07 & - & - & 1.75 & 0.20 \\
\hline Decapoda Natantia & - & - & - & - & 1.02 & 0.05 & 1.40 & 0.41 & - & - & 6.25 & 1.38 & 2.35 & 1.62 & 2.00 & 0.31 & 1.75 & 0.20 \\
\hline Crustacea unid. & - & - & 7.69 & 1.08 & 2.04 & 0.19 & $*$ & $*$ & 3.13 & 1.23 & 6.25 & 1.50 & - & - & - & - & - & - \\
\hline Total Decapoda & 3.49 & 3.02 & 9.62 & 1.22 & 18.37 & 2.59 & 10.49 & 6.53 & 20.83 & 11.64 & 25.00 & 5.76 & 18.82 & 29.95 & 36.00 & 23.96 & 26.32 & 6.93 \\
\hline MOLLUSCA & & & & & & & & & & & & & & & & & & \\
\hline Gastropoda & & & & & & & & & & & & & & & & & & \\
\hline Turritella sp. & - & - & - & - & - & - & - & - & 2.08 & 0.70 & - & - & - & - & - & - & - & 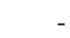 \\
\hline Cephalopoda & & & & & & & & & & & & & & & & & & \\
\hline Sepietta sp. & 1.16 & 0.14 & - & - & - & - & - & - & 8.33 & 15.85 & - & - & - & - & 6.00 & 4.82 & 1.75 & 0.26 \\
\hline OSTEICHTHYES & & & & & & & & & & & & & & & & & & \\
\hline Antonogadus megalokydon & - & - & - & - & - & - & 1.40 & 0.92 & - & - & - & - & - & - & - & - & - & - \\
\hline Argentina sphyraena & 2.33 & 1.00 & - & - & - & - & - & - & - & - & - & - & - & - & - & - & - & - \\
\hline Cepola macrophthalma & - & - & 1.92 & 0.60 & - & - & - & - & 1.04 & 0.28 & - & - & - & - & 10.00 & 11.43 & 7.02 & 3.27 \\
\hline Sardina pilchardus & - & - & 32.69 & 64.83 & 43.88 & 62.85 & - & - & - & - & 12.50 & 15.65 & - & - & 4.00 & 6.14 & 10.53 & 24.53 \\
\hline Deltentosteus quadrimaculatus & - & - & - & - & - & - & - & - & 1.04 & 0.38 & - & - & - & - & - & - & - & - \\
\hline Engraulis encrasicolus & - & - & 3.85 & 2.41 & 18.37 & 19.31 & - & - & 1.04 & 3.13 & 12.50 & 15.10 & - & - & 2.00 & 2.45 & 7.02 & 11.21 \\
\hline Gadiculus argenteus argenteus & 5.81 & 6.14 & 3.85 & 0.61 & - & - & 0.70 & 0.69 & - & - & - & - & - & - & - & - & - & - \\
\hline Gobius niger & - & - & - & - & 1.02 & 0.16 & - & - & - & - & - & - & - & - & 2.00 & 2.30 & - & - \\
\hline Lepidopus caudatus & - & - & - & - & - & - & - & - & - & - & - & - & - & - & - & - & 1.75 & 0.60 \\
\hline Lesueurigobius suerii & - & - & 5.77 & 1.46 & - & - & 6.29 & 23.76 & 8.33 & 8.90 & - & - & 0.59 & 0.23 & 18.00 & 18.49 & 10.53 & 3.84 \\
\hline Merluccius merluccius & - & - & - & - & - & - & - & - & 1.04 & 0.36 & - & - & - & - & - & - & 3.51 & 1.11 \\
\hline Mullus barbatus & - & - & - & - & 1.02 & 0.12 & - & - & - & - & - & - & - & - & - & - & - & - \\
\hline Paralepis speciosa & 1.16 & 0.21 & - & - & - & - & - & - & - & - & - & - & - & - & - & - & - & - \\
\hline Sardinella aurita & - & - & 3.85 & 2.01 & 8.16 & 11.81 & - & - & - & - & - & - & - & - & - & - & - & - \\
\hline Spicara sp. & - & - & - & - & 1.02 & 0.13 & - & - & - & - & 6.25 & 5.74 & - & - & 2.00 & 1.18 & - & - \\
\hline Trachurus trachurus & - & - & - & - & 3.06 & 0.95 & - & - & 2.08 & 4.62 & 6.25 & 3.90 & - & - & 2.00 & 1.54 & 7.02 & 6.89 \\
\hline Gadidae unid. & - & - & 3.85 & 0.68 & $*$ & $*$ & 0.70 & 0.28 & 1.04 & 2.01 & - & - & 0.59 & 0.20 & - & - & - & - \\
\hline Scorpaenidae unid. & - & - & - & - & - & - & - & - & - & - & 6.25 & 2.38 & - & - & - & - & - & - \\
\hline Triglidae unid. & - & - & - & - & - & - & 0.70 & 0.49 & - & - & - & - & - & - & - & - & - & - \\
\hline Osteichthyes unid. & 10.47 & 26.49 & 26.922 & 25.10 & 5.10 & 2.07 & 3.50 & 8.58 & 11.46 & 42.92 & 31.25 & 51.47 & 6.47 & 30.82 & 16.00 & 27.38 & 21.05 & 40.57 \\
\hline Total Osteichthyes & 19.77 & 33.84 & 82.69 & 97.69 & 81.63 & 97.41 & 13.29 & 34.74 & 27.08 & 62.61 & 75.00 & 94.24 & 7.65 & 31.25 & 56.00 & 70.92 & 68.42 & 92.02 \\
\hline
\end{tabular}

